Geo-Marine Letters

December 2006, Volume 26 (6) : Pages 373-395

http://dx.doi.org/10.1007/s00367-006-0045-z

(c) 2006 Springer. Part of Springer Science+Business

Media

The original publication is available at http://www.springerlink.com
Archimer, archive institutionnelle de l'Ifremer http://www.ifremer.fr/docelec/

\title{
Sediment distribution and evolution of sedimentary processes in a small sandy turbidite system (Golo system, Mediterranean Sea): implications for various geometries based on core framework
}

\author{
A. Gervais ${ }^{1}$, T. Mulder ${ }^{1,{ }^{*}}$, B. Savoye ${ }^{2}$ and E. Gonthier ${ }^{1}$ \\ ${ }^{1}$ Département de Géologie et Océanographie, UMR 5805 EPOC, Université de Bordeaux I, 33405 Talence \\ Cedex, France \\ ${ }^{2}$ IFREMER, DRO/GM, Environnements Sédimentaires, B.P. 70, 29280 Plouzané Cedex, France \\ *: Corresponding author : T. Mulder, email address : t.mulder@epoc.u-bordeaux1.fr, Phone: +33-5-40008847 \\ Fax: +33-5-56840848
}

\begin{abstract}
:
The Golo Margin in eastern Corsica is dissected by four canyons and two gullies which fed turbidite systems. Study of the dispersal of surficial sediments and flow dynamic in the Golo system is based on Kullenberg and interface cores interpreted in relation to a previously published seismic dataset. Cores were described in detail and interpreted within a sedimentary and stratigraphic framework. During the last 42,000 years, gravity processes which occurred in the large systems with a canyon source were mainly slide-induced, differentiated turbulent surges and hyperpycnal flows. Processes occurring in the small system with a gully source are mainly hyperconcentrated and concentrated flows. Deposits from the Corsican Margin can intercalate with products of processes triggered on the Pianosa Ridge located in the eastern part of the basin. During relative sea-level lowstands or during periods of rapid or high-amplitude sea-level fall, only large canyons (South and North Golo) are supplied by carbonate-rich hyperconcentrated and concentrated flows which are channelled in incised valleys on the shelf. During periods of slow or low-amplitude sea-level fall and during sea-level rise, sediments are trapped on a shelf delta and intensely winnowed by shelf hydrodynamic processes. Sand-rich hyperconcentrated and concentrated flows occur. All the systems fed by a canyon are active simultaneously. Gullies form and are active only during periods of sea-level rise. During relative highstands of sea level (Holocene), all the system is draped by hemipelagic sediments. Relative sealevel changes and canyon location relative to river mouths have a strong influence on the nature of sediment input, and the initiation and type of gravity flows which, in turn, control morphology and geometry.
\end{abstract}




\section{Introduction}

Our knowledge of the processes, morphology, geometry and evolution of deep-sea clastic deposits advanced considerably since Kuenen and Migliorini (1950) first suggested turbidity currents at continental margins as the possible process for their deposition. The growth patterns of deep-sea fans are strongly influenced by sea-level changes and the character of gravity flows that deposit on fan surfaces (Shanmugam and Moiola 1982; Posamentier et al. 1991; Normark and Piper 1991). Deep sea turbidite systems were intensively studied during the 1970's, essentially for their economic potential as oil and gas reservoirs (Shanmugam and Moiola 1988). However, a difference exists between the large mud and silt-dominated systems that are active at present along passive margins (e.g. Zaire, Babonneau et al. 2002; Amazon, Pirmez et al. 1997) and the small outcropping turbidite systems that formed in ancient, usually tectonically active, environments (e.g. Mutti, et al. 1996). Most modern studies deal with large deep-sea systems (see review by Stow and Mayall, 2000), and relatively few are relevant to smaller turbidite systems in which channel and sand lobes are volumetrically important. The Corsican Golo system offers such an opportunity to study a sand-rich, presently active fan at scales similar to those used during subaerial study or for 3D seismics. Another problem is the understanding and the recognition of the processes able to transport particles, especially coarse particles, over long distance down to the distal lobes. Recognition of erosion, transport and deposition process from the gravity-flow deposits is a challenge. The results concerning these sedimentary processes are particularly important to predict in which parts of the system and at which geological periods, sandy beds might be deposited. Implications are directly related to the genesis of hydrocarbon-bearing reservoir rocks.

Four types of classification exist for gravity flows:

(1) Classification based on the mechanical behaviour (rheology) of the processes (e.g., Dott (1963), Mulder and Cochonat (1996) or Shanmugam (2000). This type of classification is particularly well suited for flow processes but parameters such as viscosity of the flow are difficult to derive. 
(2) Classification based on the particle-support mechanism, matrix strength, grain-to-grain interactions, fluid support or turbulence (Middleton and Hampton 1973; Nardin et al. 1979; Lowe $1979 ; 1982)$. This is the most used classification in literature for recent deep-sea environment.

(3) Classification using flow parameters, in particular flow concentration derived from the observation of flow deposits (Mulder and Alexander 2001). It allows consideration of the flow transformation in space and time and its progressive dilution or reconcentration.

(4) Classification based solely on the sedimentary facies found along the pathway of the flow (Mutti and Ricci Lucchi 1975). It is extensively used in ancient environments and in the oil industry.

In this paper, we describe the sedimentary facies and sequences observed in the Golo turbidite system. We use these descriptions and a preliminary stratigraphic framework to describe the changes in sedimentary processes occurring in the system over the last 42,000 years.

Regional setting and previous studies

Bellaiche et al. (1993) used seismic coverage to describe several small turbidite systems along the eastern margin of Corsica. The small size of the system (total length $<25 \mathrm{~km}$ ) and the shallow water depth $(<900 \mathrm{~m})$ are of particular interest as they allow studying a whole system from the canyon head to the distal lobe with high-resolution acoustic tools.

Using the preliminary mapping of Bellaiche et al. (1993), several cruises led by Ifremer (Corstage, 1997 and 1998, Corfan, 1998, Cork, 1998), including multibeam mapping, backscatter imagery of the seafloor, high and very high resolution seismics (Boomer and Sparker) and coring accurately mapped the system and defined the boundary between turbidite systems and basin sedimentation. Gervais (2002) and Gervais et al. (2004) showed that the Golo system of Bellaiche et al. (1993) was in fact compound of four non-coalescent fans plus two sedimentary bodies that were deposited simultaneously.

Gervais et al. (2004) showed that four architectural elements at the scale of outcrop studies can be recognized in the systems in the Golo area: submarine valleys including (1) canyons and gullies, (2) sandy channels, (3) muddy levees and (4) distal lobes. A high-resolution study focusing on lobes (Gervais et al. 2006) showed the existence of processes such as avulsion, lateral migration, progradation and retrogradation. These processes were related to relative 
sea-level changes, initial seafloor topography and especially confinement, and the characteristic of sediment supply.

The Golo Margin and the general morphology of the basin

The eastern margin of Corsica is characterized by a continental slope with a lower slope gradient than on the western margin. A typical continental shelf exists on the eastern margin. Its width varies from $5 \mathrm{~km}$ in the northern area to $25 \mathrm{~km}$ to the south. In the Golo area, the width of the continental shelf varies from 9 to $12 \mathrm{~km}$. The maximum width is observed seaward of the Golo River mouth. The shelf edge is approximately at a water depth of $110 \mathrm{~m}$. Gervais (2002) and Gervais et al. (2004) detailed the morphology of this system.

The shelf is incised by several submarine valleys, from south to north: Alesani, Fium Alto, South Golo, Pineto, North Golo, Biguglia, St Damiano, Chiurlino, Bevinco and Fiuminale. Most of them lie directly offshore from a river mouth. Valleys extending from Fium Alto to St Damiano form the Golo system of Bellaiche (1993). Four of the valleys are true canyons with head incising the shelf (South Golo, North Golo, Biguglia, and St Damiano). Two of them are only gullies (Fium Alto and Pineto).

The continental slope in the Golo area deepens eastward towards the Corsican Trough. The trough is bordered by the Pianosa Ridge on its eastern flank. The Pianosa Ridge has steep flanks $\left(6^{\circ}\right.$ in the southern part) with numerous pockmarks. A large slump is located in the north part of the eastern flank. Smaller slumps occur in the southern part. The presence of both ridge and sills confine the Golo Basin.

The Golo turbidite system covers an area of $500 \mathrm{~km}^{2}$ and is located at less than $1000 \mathrm{~m}$ water depth. It is located on a narrow bulge in the continental shelf that is fed by the Golo River, which supplies particles with grain size ranging from coarse sand to clay derived from active weathering of the mountainous hinterland (Gauthier and Prone 1980; Mulder and Maneux 1999).

The South Golo Canyon is a steep $\left(3.8^{\circ}\right)$, V-shaped E-W valley with a width of $1.5 \mathrm{~km}$ and a depth (elevation between talweg and top of canyon flanks) ranging from 100 to $170 \mathrm{~m}$. The talweg is $6 \mathrm{~km}$ long. It becomes a U-shaped valley with a width of $3.5 \mathrm{~km}$ in its lower part. It is slightly sinuous ( sinuosity $=0.8$ ). Meanders and associated terraces can be observed. The south Golo turbidite system shows a channel-levee complex extending over $32 \mathrm{~km}$ with bathymetry increasing from 450 to $800 \mathrm{~m}$. The channel is bordered by levees with a maximum elevation of $55 \mathrm{~m}$ from the channel floor in the proximal part and decreasing 
downstream. At the isobath $800 \mathrm{~m}$, the channel enlarges and forms a lobe with a convex-up shape. Slope gradient is about $1^{\circ}$ on this lobe. At the beginning of the lobe, the main channel branches forming secondary channels (channelled lobe). The depth of these secondary channels does not exceed $10 \mathrm{~m}$. Their width is about $100 \mathrm{~m}$.

North Golo, Biguglia and St Damiano canyons are straight (sinuosity =1) with a V-shaped valley becoming U-shaped eastward. Their maximum depths (elevation between talweg and top of canyon flanks) are 120, 50 and $100 \mathrm{~m}$, respectively, and their lengths are 3, 4 and $2 \mathrm{~km}$, respectively. Their width is about $1 \mathrm{~km}$.

The North Golo Canyon passes over a short distance into a channel-levee complex. Channel sinuosity is 0.8 and no terraces are observed. It is bordered with well-developed levees with a maximum thickness of $35 \mathrm{~m}$. At isobath $400 \mathrm{~m}$, the channel forms a lobe with a convex-up shape and a slope gradient of about $1^{\circ}$.

The Biguglia and St Damiano systems show channels with a length of 10 and $5 \mathrm{~km}$, respectively. Levees have both low elevation and lateral expansion. They and disappear after the first kilometre. St Damiano channel is straight in its upper part and sinuous in its lower part where terraces are observed. Channel slope decreases downstream from 1.4 to 0.7.

Pineto and Fium Alto gullies do not show valley head, clear levees or terraces. They begin at water depths of 120-300 $\mathrm{m}$ for the Pineto and 120-340 $\mathrm{m}$ for the Fium Alto. They are straight (sinuosity $=0.9$ ), narrow $(250$ and $350 \mathrm{~m}$, respectively) and short (2 and $4 \mathrm{~km}$, respectively) valleys. The depth (elevation between talweg and top of gully flanks) of the Fium Alto gully decreases downstream from 50 to less than $10 \mathrm{~m}$.

The conclusions of Gervais et al. (2004) are that North and South Golo major systems present similarities to the St Damiano and Biguglia minor fans in terms of morphology and depositional architecture, but these major systems are very different from small Pineto and Fium Alto bodies.

\section{Stratigraphic framework}

A detailed stratigraphic framework was established on core MD 012434 for the last 42,000 years using radiocarbon dating, correlation with the global isotope curve (Fig. 15) and lithoseismic correlations (Gervais et al. 2004; Fig 8 to 12). The age of 42,000 yr BP at the base of the core $(24.9 \mathrm{~m})$ is provided by the isotope $\left(\delta^{18} \mathrm{O}\right)$ curve obtained on Uvigerina mediterranea and $U$. peregrina (Gervais, 2002). An age of $7340 \pm 20 \mathrm{yr} \mathrm{BP}$ was obtained on the same core at $1.5 \mathrm{~m}$ depth using a ${ }^{14} \mathrm{C}$ dating on foraminifera. A correlation could be made 
with regional seismic markers J, K and L defined by Gervais (2002) and Gervais et al. (2004; Figs 9B and C). They correspond to the latest stage of growth of the Golo turbidite system (Figs 9 and 13). The base of the recent lobe deposit (reflector K) is dated at 35,000 $\pm 220 \mathrm{yrs}$ BP (Gervais et al. 2006). Additional ${ }^{14} \mathrm{C}$ dating on cores Kco 63 and 65 allow an estimate of an age of 30,000 $\mathrm{yr}$ BP for the beginning of lobe construction. The $\mathrm{K}$ reflector (most recent lobe) is dated at around 17,000 years BP (core Kco 64; Fig. 14) and the L reflector at around 19000 years BP (Kco 65). The end of modern lobe deposition (stage J-K) is dated of around 17,400 years for the South Golo lobe (Kco 74; Figs. 9 and 14) and 18,000 years for the North Golo lobe (Kco 66). Using the SPECMAC curve and the extrapolated relative sea level changes (Lambeck and Bard 2000; Fig. 15B), interval J-K is correlated with a last fall of relative sea-level and interval K-L is correlated with the beginning of the last relative sea level rise. The interval L-surface is correlated with the end of the last relative sea level rise. The absence of ${ }^{210} \mathrm{~Pb}_{\text {exc. }}$ activity on cores that sampled the present seafloor suggests that no significant turbidite deposition occurred recently.

\section{Data and methods}

Bathymetry was collected using a multibeam echosounder SIMRAD EM 12 during the MESIM survey (Bellaiche et al. 1993). Bathymetry was processed using Caraïbe software (Ifremer). More than $1000 \mathrm{~km}$ of high-resolution seismic lines were collected during the CORFAN and CORK cruises using a $300 \mathrm{~J}$ multitip sparker, in the $200-800 \mathrm{~Hz}$ frequency range. Vertical resolution is $2-3 \mathrm{~m}$ on seismic lines and penetration is $200-300 \mathrm{~m}$. Seismic profiles were processed with the Sithere software (Ifremer). Simultaneously to seismic, 35 Kullenberg cores with an average length of $10 \mathrm{~m}$ were collected during the CORFAN and CORK cruises (1998) onboard the RV "Le Surôtt" (Fig. 1). At each coring site, a 0.85 m-long trigger core collected the very top sediment on the seafloor. A $25 \mathrm{~m}$-long Calypso core (MD 012434) was collected during the GEOSCIENCES cruise (2001) on the RV Marion Dufresne 2. Cores and seismic profiles were localised using a DGPS (accuracy about $2 \mathrm{~m}$ ).

Gamma-density, magnetic susceptibility and P-wave velocities have been measured on all cores. After core splitting, a 1-cm-thick sediment slab was collected on each split core section and X-radiographed and processed using the Scopix system (Migeon et al. 1999; Lofi and Weber 2000). The digital images were then processed using Optilab and Image SXM software. Sediment slabs were sub-sampled for selected grain-size analysis on sedimentary 
sequences and facies recognized on visual description and X-ray images and carbonate content measurements were made with a sample interval varying between 2 and $5 \mathrm{~cm}$.

Grain size was measured using a Malvern laser granulometer and carbonate content was measured using a Bernard calcimeter. Stratigraphic framework is based on AMS ${ }^{14} \mathrm{C}$ dating and sedimentary and seismic correlations (lithostratigraphy).

Sediment facies were defined according to the maximum measured grain size (sand, silt or clay). Facies percentages in core represent the proportion of the dominant facies and not the proportion of the grain-size fraction.

\section{Results}

Facies and sequences

Seven sedimentary facies have been recognized in cores from the Golo area. These facies types have been defined using: (1) photography and X-ray imagery, (2) grain-size analyses and (3) $\mathrm{CaCO}_{3}$ content. These facies can be grouped into several sequences, which are described below.

Facies 1 (homogenous, structureless clay: pelagic to hemipelagic marly ooze) is composed of centimetre to decimetre-thick structureless light brownish-grey ooze. The mean grain size is less than $10 \mu \mathrm{m} . \mathrm{CaCO}_{3}$ content is about $30 \%$ at the top of cores and about $15-20 \%$ when associated with other facies. Facies 1 is found over almost the whole area. Near the Pianosa Ridge, high concentrations of monosulfides are also observed.

Facies 2 (homogenous, structureless silty-clay) consists of thin (few centimetres) to thick (around one metre) intervals of structureless olive-grey clay, with abundant monosulfides. The mean grain size ranges from 10 to $20 \mu \mathrm{m}$ and $\mathrm{CaCO}_{3}$ content is about $15 \%$. Locally, near the shelf and Pianosa Ridge slumps, carbonate content reaches $25 \%$.

Facies 2 and 1 are usually associated together. They form grey-olive silty-clayey beds grading into homogeneous grey-olive clay. Lower and upper contacts are gradational and in some cases difficult to observe. Thickness of beds made of these two facies varies from a few centimetres to several tens of centimetres. They are observed in all cores but mainly on the levees of the south Golo system and on the lobe fringes of the South and North Golo and Pineto systems. 
Facies 3 (massive silt) consists of a thin (few centimetres) layer of silty clay. Bioturbation is very abundant. The mean grain size is around $30 \mu \mathrm{m}$ and $\mathrm{CaCO}_{3}$ content ranges from 10 to $15 \%$. This facies shows bioturbated, disrupted contacts or gradational contacts at the base and top. Some intervals present fine sand lenses and crude planar laminae (in cores on the distal south Golo and Pineto lobes). Main constituents are abundant micas and shell fragments, and benthic and planktonic foraminifers.

Facies 4 (massive or with various dynamic structures graded fine sand) consists of beds of a few centimetre-thick fine sand. The absence of structures during the visual description made first the interpretation of these beds difficult. The X-radiographs of sediment slabs, however, revealed several types of facies and small-scale sedimentary structures within the sand beds. They can be massive or with structures: wavy parallel or convoluted laminae, diffuse laminae, or climbing ripples (Fig. 2A). The mean grain size is around $50 \mu \mathrm{m}$, and $\mathrm{CaCO}_{3}$ content is less than $10 \%$. Main constituents are subrounded quartz, abundant micas and shell fragments, benthic and planktonic foraminifers.

Facies 5 (laminated graded sand) consists of centimetre to several decimetre-thick medium- to coarse-sand beds. The mean grain size varies from 63 to $200 \mu \mathrm{m}$, and $\mathrm{CaCO}_{3}$ content is less than $15 \%$. Some intervals present higher carbonate content, about $30 \%$. Numerous inframillimetric laminae are visible on X-ray images (Fig. 2B). The number of laminae increases from the bottom to the top of a single bed, as grain size decreases.

Facies 6 (massive sand) consists of massive centimetre to metre-thick medium- to coarsesand beds. The mean grain size varies between 90 and $250 \mu \mathrm{m}$, and $\mathrm{CaCO}_{3}$ content is less than $10 \%$. Near the shelf and the slumps on the Pianosa slope, some centimetric levels exhibit high carbonate content around $25 \%$. Some levels show centimetric mud clasts of facies 1 (Fig. 2C). The main constituents are similar to those described in facies 5 and 6 : subrounded quartz, abundant micas and millimetric shell fragments, and benthic and planktonic foraminifers.

Facies 7 (coarse homogeneous shelly sand) is made of homogeneous, and unsorted coarseto medium-sand with very abundant millimetric to centimetric shell fragments (Fig. 2D). The mean grain size varies from $63 \mu \mathrm{m}$ to $2 \mathrm{~mm}$. The $\mathrm{CaCO}_{3}$ content ranges from 35 to $70 \%$. This facies consists of subangular quartz, with very coarse and fine shells organisms or fragments (coral, gasteropods, pteropods, bivalves, and foraminifera). This facies is only observed in shelf deposits and locally on the northern Pianosa slope. 
Sequence I fines upward (Figs. 3 and 4) and consists from base to top, of the following superposition of facies 6 to 2: massive sand $(<5 \mathrm{~cm})$, laminated sand (few $\mathrm{cm}$ to $20 \mathrm{~cm}$ ) with number of lamina increasing upward, fine sand (few $\mathrm{cm}$ ) that can be massive, cross-laminated or with silt lenses, silt, silty clay (1 to few $\mathrm{cm}$ ) and clay ( $\mathrm{cm}$ to $\mathrm{dm})$. The basal contact is erosive. The upper contact is sharp to gradational. It is the most abundant sequence in the study area, but is only located along the South Golo channel.

Sequence I is usually truncated (Itr in Fig. 4). Three sub-sequences can be found:

(1) Sequence Itra consists only of fine sand, silt and clay. Facies 6 and 5 are absent (Fig. 4). The basal contact is erosive. The upper contact is sharp to gradational. The contact between sand and silt is usually sharp. The sandy facies can show undulating laminae, cross lamination, and convolute or deformed laminae.

(2) Sequence Itrb consists only of silt and clay. The three sandy lower facies are absent (Fig. 4). Lower contact is sharp and deformed. Upper contact is usually gradational. The silty facies (mean thickness of $5 \mathrm{~cm}$ ) is either massive or exhibits silty clay lenses. This sequence is observed on the upper levee and the distal lobe of the South Golo System and in the distal lobes of the Pineto gully.

(3) Sequence Itrc consists only of massive sand and clay. The sequence I is truncated of the laminated and fine sand and silt. This sequence is thin (thickness $<5 \mathrm{~cm}$ ) and is observed in the Fium Alto lobe in addition to the distal part of the South Golo channel.

Sequence II (Figs. 3 and 5) consists of centimetre to decimetre-thick, coarse to medium massive sand (facies 6) grading to silty clay through an intra sequence sharp contact. Carbonate content is usually high (app. $30 \%$ ). The basal contact is sharp to erosive and the upper contact is sharp. Grading in this sequence is absent or poorly developed. This sequence is observed on the St Damiano levee and on the side and lobe of Fium Alto.

Sequence III (Fig. 3) consists of metre-thick massive sand (facies 7) with no grading and scattered centimetre to decimetre-thick silty-clay clasts. Both basal and upper contacts are erosive. This sequence is observed on the distal part of the South Golo channel and in lobes (South and North Golo, Pineto and Fium Alto).

Regional sedimentary map and litho-seismic correlations 
Using the previously published seismic dataset (Gervais et al. 2004), the sedimentary distribution identified on cored bodies (Fig. 6) can be extrapolated to the whole Golo margin (Fig. 7) to provide the distribution of lithofacies on the Golo system.

The continental shelf is characterized by coarse massive shelly sand facies associated to bedded, high-amplitude seismic facies (Figs. 6 and 7). Interfluves and Pianosa slope are characterized by silty-clay and by continuous to discontinuous bedded seismic facies (Figs. 6 and 7). Two slumps have been mapped along the slope of the Pianosa Ridge (Fig. 7). The northern slump corresponds to chaotic seismic facies associated with massive shelly sand (Figs. 7 and 8). The southern slump, near the South Golo lobe, corresponds to silty-clayey deposits with abundant monosulfides and to continuous to discontinuous transparent seismic facies (Figs. 7 and 8). This lithofacies is also observed on the eastern part of the lobe. Core Kco 74 collected in the distal part of the lobe allows a good litho-seismic correlation particularly with boomer data (Fig. 9).

Channels are characterized by sandy facies (Fig. 6) with abundant sedimentary structures (Fig. 10) and by chaotic seismic facies with hyperboles or very high-amplitude bedded seismic facies (Fig. 7 and Kco 62 in Fig. 9). Major channels show numerous sequences I and I-tr (lacking upper silty-clay units) and massive sequences III (Fig. 10).

Levees of major systems are composed of silty-clay facies alternating with some sequences I-tr (lacking upper silty-clay units) (Fig. 10) and associated with continuous bedded divergent seismic facies (Fig. 7). Levees of minor systems (Biguglia and St Damiano; Fig. 11) and flanks of Pineto and Fium Alto gullies (Fig. 12) are sandier than levees of major systems and characterized by sequence II. Carbonate content is higher in levees of minor systems than in levees of major systems and seismic bedded divergent facies present higher amplitude than levees of major systems (Figs. 6 and 7). 
Lobes are mostly characterized by massive coarse sand (sequence III) (Figs. 13 and 14) associated with chaotic seismic facies (Fig. 7). Numerous sequences I-tr are observed in the South Golo small secondary channel-lobe associated with high amplitude bedded facies (Kco 62 in Fig. 9). Mud clasts are generally observed in proximal lobe and sand content decreases downlobe (Fig. 6). Distal major lobes are characterized by small turbidite activity (sequence II-tr in core Kco 73; Fig. 6), whereas no turbidite is described for Pineto lobe characterised by silty-clay beds and continuous bedded seismic facies.

\section{Discussion}

\section{Sedimentary processes on the margin}

Facies 2 and 1 with high carbonate content $(30 \%)$ and abundant bioturbation are interpreted as hemipelagites. They drape the whole study area.

The remaining facies are discussed in terms of the sequences that they form. The presence of a sharp or erosive basal contact associated with a normal grading (Kuenen and Migliorini 1950 ) is usual criteria to distinguish waning flow (Kneller 1995) corresponding to a turbulent surge (Middleton and Hampton 1973). In that case, sequence I can be interpreted as classical Bouma sequence where massive or poorly graded sandy facies at the base of the sequence corresponds to the freezing of a concentrated flow (Mulder and Alexander 2001) equivalent to Ta unit of the Bouma sequence and the superposed facies correspond to the deposition by a turbulent flow (type 1 flow). Sequence I correspond to the deposition by a sandy flows with a thin laminar lower part and a thick turbulent upper part. Truncation of the base of sequence I (sequences Itra, Itrb and Itrc) suggests a more distal deposition from the flow source than in places where the whole sequence is observed.

Sequence II can be interpreted similarly to the base of sequence I. It results from deposition by a concentrated flow (Ta unit). The high carbonate content suggests a direct supply from the continental shelf where biologic activity is the most intense.

Sequence III consists of massive sand. Several types of flows can generate massive sands: laminar grain flows of Middleton and Hampton (1973), debris flows (Nardin et al. 1979), 
sustained turbidity currents (Kneller 1995) or hyperconcentrated flows (Mulder and Alexander 2001). The presence of floating mudclasts suggests the existence of upward dispersive pressure associated with buoyant lift due to a fine-grained matrix (Lowe, 1982). This characteristic associated with both sharp basal and upper contacts and absence of grading (or a crude inverse grading) suggests a deposit resulting from a laminar flow. The presence of a poorly-graded or massive facies suggests that sequences III are deposited by sandy hyperconcentrated flows with a thick laminar basal part despite a turbulent upper part might exist (type 2 flow).

\section{$\underline{\text { Sedimentary processes in canyons }}$}

Because flows do not spill over canyon walls, the maximum flow thickness can be estimated using the height of these walls. Consequently, flow thickness does not exceed 170 and $120 \mathrm{~m}$ in South Golo and North Golo canyons, respectively. The presence of terraces suggests that nested levee forms (Pichevin et al. 2003). Gervais (2002) already demonstrated that slumping occurs of the canyon flanks. These slumps could be at the origin of some of the terraces (see Gaudin et al. this volume).

Deposits in canyons of small sedimentary systems (Biguglia, St Damiano) are mainly sequences of type III with high carbonate content, especially in the upper part of the canyons. This suggests canyons are by-pass area. Deposition occurs only from thin hyperconcentrated flows generated by slumps initiated close to the shelfbreak. These hyperconcentrated flows are not able to spill and to build extended channel-levee complexes.

\section{$\underline{\text { Sedimentary processes in channel-levee complex }}$}

The proximal (upper) part of the South Golo channel, shows meanders. Meandering suggests that flows are relatively continuous through time (Babonneau et al. 2004). Using elevation of levees, flow thickness in this area decreases from 70 to $35 \mathrm{~m}$.

The proximal South Golo levee shows facies association 2 and 1 and only one centimetricscale Itrb sequence (Kco 40 and 39 in Fig. 10). No sand is observed. This could be explained by the shortness of cores collected on this levee. Downstream, cores on the distal levee are still dominated by silty clay facies showing sequences with increased proportion of silty to sandy facies (Kco 59 and 60 in Fig. 10). Presence of numerous sedimentary structures including laminae suggests a slow rate of deposition from an individual flow. In particular, the increase of number of laminae in the top part of sequence and the normal grading of laminae suggests that fluctuations occurs at a high rate within the basal boundary layer of the 
flow. Such pulses have been described by Hesse and Chough (1980), Migeon (2000) and Migeon et al. (2001).

In the channel, numerous centimetre to decimetre-thick sandy sequences (I and I-trc) are observed (Kco 58 and 61 in Fig. 10). This suggests that flows channelised in that area are almost fully turbulent with a thin laminar basal concentrated flow. Sequences II are also observed in the upper part of the core (Fig. 10). The Kco 61-58-59-60 transect from channel axis to outer levee (Fig. 10) illustrates rapid decrease of proportion of sandy facies and mean grain size and thinning of sandy beds (Figs 6 and 10). Sand content decreases respectively from $32 \%$ in the channel to $3 \%$ in the proximal levee and $0 \%$ in the outer levee. Mean grain size is about $200 \mu \mathrm{m}$ in the channel (Kco 58) and only $70 \mu \mathrm{m}$ on the proximal levee (Kco 59). These observations suggest that levee in this area forms because a classical flow spilling process (Hiscott et al. 1997). The finest upper part of a turbulent surge flowing in the channel spills over the channel sides and deposits fine-grained Bouma sequences.

Core collected on the upstream part of the St Damiano levee is composed of $90 \%$ of carbonated silt (Kco 79 in Fig. 11). Kcor 01 collected on the downstream part of the St Damiano channel is composed of $25 \%$ of sand (Fig. 11). Massive centimetric to decimetric sandy carbonated sequences II are observed (Fig 11). This suggests that processes in St Damiano system are hyperconcentrated to concentrated laminar flows (type 2) resulting from the differentiation of failures initiated on the upper slope, close to the continental shelf.

\section{$\underline{\text { Sedimentary processes in channelled lobes }}$}

Cores have been collected on both North and South Golo lobes. The actual lobe of the South Golo system has a radiate shape suggesting coarse-grained deposits (Reading and Richards, 1994) deposited by flow that rapidly deflate after mouth of channels. Proximal (upper) lobe sequences are of type III with decimetric- to metric-scale massive structureless coarse sand (Fig. 14). In the distal (lower) part of both lobes (Kco 66 for North Golo lobe and Kco 74 for South Golo lobe in Fig. 14), the deposits belong to sequence Itrb. Unusual high carbonate content $(70 \%)$ is measured in sandy North Golo sequences suggesting a flow initiation close to the continental shelf. In the South Golo lobe (Kco 74), sandy sequence alternate with monosulfide-rich silty-clay (facies 2; Fig. 14). These lobe sequences are interpreted as the result of deposition by thin hyperconcentrated flows with a high sand content and a thick basal laminar part. This suggests that thickness of the basal laminar part progressively increased in the channel-levee system because of the progressive deposition of fine particles on the levees through spilling. The sequences I trb could be deposited by 
turbulent flow not enough thick to spill over the levees. Because they are deposited by turbulent (type 1) flow, deflation is less intense than for type 2 laminar flows. Type 1 turbulent flows travel farther away after channel termination and sequences Itrb are deposited more distally on the lobe than type III sequences. Sand content is very high and decrease downlobe from generally more than $50 \%$ in the proximal lobe (Kco 62-63-64 and Kco 71-72 in Fig. 6) and less than $10 \%$ in the distal lobe (Kco 73-74 and Kco 66 in Fig. 6). This high sand content explains the quick deflation of flows at the channel end and the radiate shape of the lobe.

Lobes of small sedimentary systems (Biguglia, St Damiano) have a more elongate shape than larger systems but are thinner and smaller. The global volume of sand entering these small systems is smaller than for larger systems such as South Golo. Consequently, flow deflation is less intense at channel termination than for larger systems.

\section{$\underline{\text { Sedimentary processes on lobe fringe }}$}

The recent lobe fringe of the South Golo system is characterized by a decrease in both frequency of turbidite sequences and sand content. The only observed sequences are basetruncated of sequences type II. They are interbedded with monosulfide-rich clay. This suggests that lobe fringe is rarely affected by turbidity currents. Only the largest currents are able to transport and deposit sediments in this part of the system. Seismic data (Figs. 9) shows that the large slumps initiated on the Pianosa Ridge and on the Corsican slope located south of the Golo System (Fig. 16) probably generated flows that reached the South Golo lobe fringe. However, no sedimentary evidence is observed in cores.

The North Golo lobe fringe is characterised by complete and truncated type I sequences with high carbonated content. The upper part of the lobe deposit does not show high carbonate content. This eliminates Corsican shelf as carbonate source. The northern slump of the Pianosa Ridge corresponds to chaotic seismic facies associated to massive shelly sand (Kco 69 in Fig. 6). The only source for deposits with such high carbonate content is the Pianosa Ridge. The large slump observed on the north part of the Pianosa Ridge probably generated flows supplying the fringe of the North Golo lobe (Fig. 16) and interbedded with turbidite deposits from the Corsican margin.

\section{$\underline{\text { Sedimentary processes in Pineto and Fium Alto gullies. }}$}


Cores collected on the flanks of these gullies are composed by centimetre to metre-thick silt and sand beds representing up to $80 \%$ of the core (Kco 54-27-28-35 in Figs 6 and 12). Sequences are mainly of type III with high carbonate content (Kco 35 in Fig. 12), suggesting hyperconcentrated flows with a thick laminar basal part are the dominant process. The sand/clay ratio compares with values obtained on small-sized systems. The presence of truncated sequences type I suggests that turbulent flow may also travel in these gullies and that flow differentiation occurs sometimes along the steep slopes of the gullies.

Downstream, on lobes, percentage of sandy facies ranges between 10 and $20 \%$, except in Kco 77 where massive sandy metric sequence III is observed (Kco 55-56-42-77 in Figs 6 and 12). Centimetre to decimetre-thick laminated sandy sequence Itrc and centimetric massive sequence III are observed. This confirms that flows can differentiate slightly longitudinally in these small gullies. Downstream from Pineto lobe, no sequences corresponding to gravity processes deposits are observed. Core Kco 57 (Fig. 6) contains more than $10 \mathrm{~m}$ of silty-clay to clay suggesting no fine-grained turbidity current deposited here during recent times.

Origin of flow feeding the Golo System

Flows can be initiated by two kinds of processes: (1) direct supply by rivers and (2) sediment failures (Fig. 16).

On the Golo margin, direct supply by rivers is suggested by the connection between canyons and rivers. This connection is interrupted at present on the continental shelf but was direct during periods of sea level lowstands. The Golo River provides coarse sand material. The presence of incised valleys on the shelf (Gervais 2002; Gervais et al. 2004) suggests that canyon began to form during Plio-Quaternary in a subaerial setting. However, the freshness of canyon flanks suggests that canyon morphology is maintained until Holocene by frequent activity of continuous flows. These flows can either be hyperpycnal flows of Mulder and Syvitski (1995) or frequent turbulent surges triggered by successive failures on the upper continental slope or at the shelfbreak when sediment load is high at river mouths. A direct initiation of turbidity currents by hyperpycnal flows triggered during river floods is also suggested by the direct connection of canyons and rivers through incised valleys that occur especially during sea level lowstands. In addition, the most developed canyon (South Golo) is presently connected to the most important river (Golo River).

Sediment failures can transform into turbidity current either by progressive dilution, fine sediment elutriation or because of slope roughness creating hydraulic jump within the flow (Fisher 1983). During periods of high sediment supply at river mouths, the time of residence 
of sediment on the continental shelf is short and fine sediment are not winnowed or removed: flow with a thick turbulent upper part can form. During periods of low sediment load at river mouths, sediments are trapped on the continental shelf and fine particle are winnowed and removed by shelf processes. Hyperconcentrated flows with high carbonate content resulting from the transformation of slide or slumps initiated close to the shelf break can thus form. During these periods, a shelf delta can prograde. This would explain the simultaneous activity of all the canyons (Gervais 2002; Gervais et al. 2004). The delta would thus distribute the river sediment supply along the margin.

\section{Conceptual model of sedimentation on the Golo Margin}

Core dating confirms and provide more precision for the previous conceptual model of the Golo system growth during the late Quaternary (Gervais et al. 2004). During interglacial highstands such as present time, no turbidite activity was observed. At 18,000 years BP, there was a drastic change in flow dynamic, frequency and sediment distribution. Four periods with a different turbidite activity can be distinguished (Fig. 17):

(1) Slow and low amplitude sea-level fall (seismic stage I-J or isotopic stage 3; Fig. 17a). The continental shelf remained submerged. A delta prograded on the continental shelf. Distributaries on the delta supplied all the canyons with turbidity currents. As the sediments were trapped temporarily on the delta that lied on the continental shelf, flow initiation was dominated by sediment failures close to the shelfbreak. These failures transformed into hyperconcentrated or concentrated flows with a thick laminar basal part. These flows were usually sand-rich because fine particles were intensively winnowed by shelf processes such as shelf currents or littoral drift. On the Celtic margin, Zaragosi (2001) described tide intensity two times higher during lowstands of sea level than during highstands. However, as rivers were connected to the slope through delta distributaries, hyperpycnal flows could have acted simultaneously with other processes. Levees and lobes growth was moderate (average sedimentation rate was $2 \mathrm{~m} / 1000$ yrs in lobes).

(2) Rapid and high-amplitude sea-level fall or sea-level lowstands (seismic stage J-K or isotopic stage 4; Fig. 17b). The continental shelf was not submerged. During stage J-K, sea level is $110 \mathrm{~m}$ lower than present. This period was characterized by intense activity of gravity processes in the basin (Gervais et al. 2004). The delta prograded rapidly on the upper continental shelf and the river eroded intensively to reach its equilibrium profile. Sediment load was high on the shelf. However, only large canyons such as South and North Golo canyons were supplied by sediment as sediment flux on the shelf is concentrated in incised 
valleys. During these periods, sediment processes on the slope were dominated both by mixed (mud and sand) turbulent surge with a thin basal concentrated flow and a thick upper turbulent part (type 1) and probably by hyperpycnal flows. During these periods of high sediment supply, residence time on the shelf was short and leads to little winnowing of fine particles. Average sedimentation rates on the margin were $5 \mathrm{~m} / 1000$ yrs on lobes, $3 \mathrm{~m} / 1000$ yrs on upper channel-levee complexes and $2 \mathrm{~m} / 1000$ yrs on lower channel-levee complexes. Avulsion rate was important both on channel-levee complexes and in channelled lobes. This period also corresponded to important levees growth due to overspill of the upper turbulent part of flows. However, spilling was not frequent. Core dating allows to calculated spillover frequency for the period 19,000 -18,000 years BP (Kco 59 and Kco 62 in Figs. 10 and 14). One spillover deposit was deposited every 200 years and one event produces preserved deposits in a channel every 50 years. This suggests that most of the flows were only channelled and did not spill. This rate of spilling is low when compared to large muddy systems such as Zaire (Migeon 2000). The presence of sand on levee deposits suggests that flows moving in the system had a high sand/clay ratio. This high sand content explains the lack of sedimentary structures in deposits. When spilling occurs, flows quickly decelerate and grain to grain interaction generates a quick deposition (frictional freezing) of sand, preventing for lamina formation.

(3) Sea-level rise (seismic stage K-L or isotopic stage 3; Fig. 17c). Geometry of sedimentary bodies observed on seismic data suggests that flow activity changed with time on channellevee systems (Gervais 2002; Gervais et al. 2004). During interval K-L, no spillover was observed on levee cores (KCO58). Hyperconcentrated flows were the dominant process in large systems. Flow frequency was higher than during period (2). Core dating provides a rate of one event every 30 years in major channels. During times of rising sea level, such as during the period extending from 18,000 years BP until Holocene, sandier sequences are described in all fans and gullies of the margin and no levees growth is observed (Kco 59 in Fig. 10). Core dating allows determining that the thin lobe deposits were restricted to the Younger Dryas during relative rising sea level (Kco 58 in Fig. 10). Deposition occurred on the shelf delta. It began close to the shelfbreak and retrograded progressively upper on the continental shelf. As river profile was below its equilibrium profile, sediment supply was low due to the general of retrograding trend in the delta. In addition, fine particles were winnowed by shelf processes as the shelf becomes progressively submerged. Turbidite activity was low and dominated by sand-rich hyperconcentrated and concentrated flows with a high carbonate content. However, the sediment that piled-up during the preceding sea-level lowstand generated overloading and 
oversteepening. The flooding of the coarse sediments deposited the preceding sea-level lowstand reduced their shear resistance by decreasing their friction angle generating easily slope failures. In addition, excess pore pressure generated by hydrodynamic processes on shelf (e.g., storm waves, swell, wind-induced currents) helped to generate sediment failures. These failures transformed in hyperconcentrated and concentrated flows with a thick laminar basal part and a thin turbulent upper part. These failures and flows occurred both in all the canyon heads and anywhere along the shelfbreak, initiating gully formation. These observations suggest that gullies have a different origin than canyons. Gullies head is located at the shelfbreak. They are not connected to a continental river system or to a network of valleys on the continental shelf. According to seismic profiles (Gervais 2002; Gervais et al. 2004), their activity was restricted to the period 19,000-15,000 (stage K-L) corresponding to the beginning of the last sea-level rise. Gullies would then be related to the destruction of the shelf delta that built during the preceding period of sea-level lowstand. They would result from the transformation of retrogressive submarine failures in hyperconcentrated or concentrated flows. This short period of activity for gullies is drastically different of what is described by Field et al. (1999) on the Californian margin. On the Golo margin, gullies never represent an initial stage of canyon formation.

(4) Sea-level highstands (seismic stage L-surface or isotopic stage 1; Fig. 17d). No turbiditic activity occurred. Sediments were trapped on the shelf but the finest part was transported to the basin by hypopycnal flows that formed the hemipelagic drape when mixing with the pelagic particles. Sedimentation rate was low on the whole margin $(0.3 \mathrm{~m} / 1000 \mathrm{yrs})$ which is consistent with values published by Stanley et al. (1980).

The difference in process feeding is related to canyon positions in regard to source area. Thus, the location of a turbidite system with respect to the river source location will determine the main feeding processes (quasi-continuous currents or short duration flows) and the periods of major supply. (1) Major canyons are preferentially fed by large-volume mud/sand-rich flows due to their proximity to the river mouth. Consequently, major systems, located in front of the rivers, are mainly fed by a persistent mud/sand rich point-source (sandy flows with a thin laminar lower part and a thick turbulent upper part or type 1 flows) during periods of sea level lowstands or fall, leading to the construction of deep, stable, more or less sinuous channels with well-developed levees and large and thick lobes in the distal part of the basin (Gervais et al. 2004). Avulsion rate is high and progressive lateral migration is important (2) Minor systems, located far from the river mouths are also fed by these types of currents 
during sea level lowstands, but mainly by sandy flows (sandy hyperconcentrated flows with a thin turbulent upper part or type 2 flows) that may be generated by shelf storms or failures in canyon heads during periods of both sea level rise or fall. This leads to the construction of unstable, relatively straight channels with low sandy levees. Only avulsions and small thin lobes are observed in the proximal part of the basin (Gervais et al. 2004). The morphology of the basin, including slope value has also a great impact on the transport capacity of flows. For example, during stage K-L sandy flows predominate. The pre-existing well-developed channel-levees complex drains sediment transport and allows sandy flows to form small lobe in the basin (major fans). Simultaneously, minor fans and gullies form small lobes along the slope or in the proximal basin.

\section{Conclusions}

Three types of flow contribute to the construction of the Golo system: (1) turbulent, sandrich concentrated flows with a strong vertical density contrast. The basal part of the flow is laminar and the top part is turbulent. (2) Continuous flows (hyperpycnal) with both sand and mud. (3) sand-rich flows with higher concentration than (1) and (2) and with a basal laminar part thicker than (1) and (2). Deposits from flow initiated on the Pianosa Ridge are interbedded with sediment coming from the east Corsican margin.

During relative sea level lowstands and sea-level falls, flows were initiated either by direct supply from the river mouth and through shelf delta channels, or by slope failures. Sediment supply was continuous and fine-grained particles were not winnowed. Concentrated flows with both sand and mud were the most frequent processes. This favoured levee construction and lobe progradation. Channels were stable and moved only by progressive migrations. During relative sea-level rises, the four canyons located in the studied area were supplied. Flows were triggered by slope failures in the shelf carbonate-rich sediments with a low content in fine particles. Sediments supplied by rivers were trapped on the shelf and finegrained particles were winnowed. Levee and lobe construction was low and the volume of sediment was lower than during sea level lowstands. During sea level highstands, and in particular the Holocene, a hemipelagic drape settled in the whole area.

In this type of confined sandy margin, relative sea level changes and potential connection between canyon and sediment source both have a strong influence on the quantity and quality of sediment supply to the basin. Sea level changes determinate the characteristics of sediment 
input and canyons connection to the source is the major factor controlling the dominant transport process and its initiation that in turn control the system morphology and geometry. The characteristics of sediment input and the initiation mechanism of gravity flows are the most important variables in the whole Golo system, because they influence the morphology and geometry of individual sedimentary bodies.

Mass-transport process can also be initiated outside of the turbidite systems of the Golo margin, for example on the continental slope of the Pianosa Ridge. In this case, debrites or slump deposits can intercalate with gravity-flow deposits coming from the Golo turbidite system. Because of the confinement, several sediment sources are observed, explaining the complexity and the interplay of sedimentary processes. However, the morphology of the basin, including pre-existing topography (various slope gradient, well-developed channellevee complexes) and confinement have a great impact on the distribution geometry and the long-term growth pattern, constraining more or less the flows.

\section{Acknowledgements}

The authors are grateful to IFREMER for data availability. Multibeam bathymetry and seismic data have been compiled by A. Normand, E. LeDrezen and S. Zaragosi. Authors thank J. Saint-Paul, G. Chabaud, D. Poirier, R. Apprioual, G. Floch and R. Kerbrat for their technical assistance during core studies. Authors thank David Piper and Sébastien Migeon for their useful critics on this paper. This paper is UMR-CNRS 5805 EPOC contribution $\mathrm{n}^{\circ} 1584$.

\section{References}

Babonneau N, Savoye B, Cremer M, Klein B (2002) Morphology and architecture of the present canyon and channel system of the Zaire deep-sea fan. Mar and Petrol Geol $19(4): 445-467$

Babonneau N, Savoye B, Cremer M, Bez M (2004) Multiple terraces within the deep incised Zaire Valley (ZaiAngo Project): Are they confined levees? In Lomas S, Joseph P (eds) Confined Turbidite Systems. Geol Soc London Spec Publ 222, pp 91-114 
Bellaiche G, Pautot G, Gaullier V, Vanney JR, Droz L (1993) Les appareils sédimentaires de la marge orientale de la Corse: interprétation hydrodynamique et implications structurales. Mar Geol 316 513-517

Dott RH (1963) Dynamics of subaqueous gravity depositional processes. AAPG Bull 47:104128

Field ME, Gardner JV, Prior DB (1999) Geometry and significance of stacked gullies on the northern California slope. Mar Geol 154:271-286.

Fisher RV (1983) Flow transformations in sediment gravity flows. Geology 11:273-274

Gauthier A, Prone A (1980) Histoire des sables dans un basin fluviatile par exoscopie des quartz; Example du Fium'Orbo (Corse). Bull Soc Géol Fr 22(1):16-20

Gervais A (2002) Analyse multi-échelles de la morphologie, de la géométrie et de l'architecture d'un système turbiditique sableux profond (système du Golo, marge est Corse, mer Méditerranée). Ph.D. thesis, Univ. Bordeaux 1, n²621, 288 p

Gervais A, Savoye B, Mulder T, Piper DJW, Cremer M, Pichevin L (2004). Present morphology and depositional architecture of a sandy submarine system: The Golo turbidite system (Eastern margin of Corsica). In: Joseph P, Lomas SA (eds) Confined Turbidite Systems. Geol Soc London Spec Publ 222, pp 59-89

Gervais A, Savoye B, Mulder T (2006) Sandy modern turbidite lobes. Are-they massive sand? A new insight from high resolution seismic data. Mar and Petrol Geol (in press)

Hesse R, Chough S.K (1980) The Northwest Atlantic Mid-Ocean Channel of the Labrador Sea: II. Deposition of parallel laminated levee-mud from the viscous sublayer of lowdensity turbidity currents. Sedimentology 27:697-711

Hiscott RN, Hall FR, Pirmez C, 1997. Turbidity current overspill from the Amazon Channel: texture of the silt/sand load, paleoflow from anysotropy of magnetic susceptibility, and implications for flow processes. In: Flood RD, Piper DJW, Klaus A, Peterson LC (eds) Proc ODP, Sci Results, 155, College Station TX, pp 53-78

Kneller BC (1995) Beyond the turbidite paradigm: physical models for deposition of turbidites and their implications for reservoir prediction. In: Hartley AJ, Prosser DJ (eds) Characterization of Deep Marine Clastic Systems. Geol Soc London Spec Publ 94, pp 3149

Kuenen PH, Migliorini CI (1950) Turbidity currents as a cause of graded bedding. J Geol 58:91-127

Lofi J, Weber O (2000) The use of SCOPIX X-ray images for the extraction of a high resolution sedimentary signal. Geo-Mar Lett 20(3):182-186 
Lowe DR (1979) Sediment gravity flows: their classification and some problems of application to natural flows and deposits. In: Doyle NJ, Pilkey OH (eds) Geology of Continental Slopes. SEPM Spec Publ 27, Tulsa, pp 75-82

Lowe DR (1982) Sediment gravity flows: II. Depositional models with special reference to the deposits of high-density turbidity currents. J Sediment Petrol 52:279-297

Middleton GV, Hampton MA (1973) Sediment gravity flows: mechanics of flow and deposition. In: Middleton GV, Bouma AH (eds) Turbidity and Deep Water Sedimentation. SEPM Pacific Section, Short Course Lecture Notes, pp 1-38

Migeon S (2000) Dunes Géantes et levées Sédimentaires en domaine marin profond: Approches Morphologique, Sismique et Sédimentologique. Ph.D. thesis, Univ. Bordeaux I, $288 \mathrm{p}$

Migeon S, Savoye B, Zanella E, Mulder T, Faugères J-C, Weber O (2001) Detailed seismicreflection and sedimentary study of turbidite sediment waves on the Var sedimentary Ridge (SE France): significance for sediment transport and deposition and for the mechanisms of sediment-waves construction, Mar and Petrol Geol 18:179-208

Migeon S, Weber O, Faugères J-C, Saint-Paul J (1999) SCOPIX: a new X-ray imaging system for core analysis. Geo-Mar Lett 18:251-255

Mulder T, Alexander J (2001) The physical character of sedimentary density currents and their deposits. Sedimentology 48:269-299

Mulder T, Cochonat P (1996) Classification of offshore mass movements. J Sediment Res $66: 43-57$

Mulder T, Maneux E (1999) Flux et bilan sédimentaires. Impact des apports fluviatiles sur la construction des éventails sous-marins profonds de la marge Est-Corse, Internal Report, Univ. Bordeaux I

Mulder T, Syvitski JPM (1995) Turbidity currents generated at river mouths during exceptional discharges to the world oceans. J Geol 103:285-299

Mutti E, Davoli G, Tinterri R, Zavala C (1996) The importance of ancient fluvio-deltaic systems dominated by catastrophic flooding in tectonically active basins. Sci Geol Mem 48:233-291

Mutti E, Ricci Lucchi F (1975) Turbidite facies and facies association. In: Mutti E, Parea GC, Ricci Lucchi F, Sagri M, Zanzucchi G, Ghibaudo G, Iaccarino S (eds) Example of Turbidite Facies Associations from Selected Formation of Northern Apennines. IAS Congress Nice, pp 21-36 
Nardin TR, Hein FJ, Gorsline DS, Edwards BD (1979) A review of mass movement processes, sediment and acoustic characteristics, and contrasts in slope and base-of-slope systems versus canyon-fan-basin floor systems. In: Doyle LJ, Pilkey OH (eds) Geology of Continental Slopes. SEPM Spec Publ 27, Tulsa, pp 61-73

Normark WR, Piper DJW (1991) Initiation processes and flow evolution of turbidity currents: Implications for the depositional record. In: Osborne RH (ed) From Shoreline to Abyss; Contribution in Marine Geology in Honor of Francis Parker Shepard. SEPM, Spec Publ 46, Tulsa, pp 207-230

Pichevin L, Mulder T, Savoye B, Cremer M, Piper DJW, Gervais A (2003) The Golo submarine system (east-Corsica margin): turbidite system morphology and processes of terrace formation from high-resolution seismic Boomer profiles. Geo-Mar Lett 23(2):117124

Pirmez C, Hiscott RN, Kronen JK Jr (1997) Sandy turbidite successions at the base of channel-levee systems of the Amazon Fan revealed by FMS logs and cores: unravelling the facies architecture of large submarine fans. In: Flood RD, Piper DJW, Klaus A, Peterson LC (eds) Proc ODP, Sci Results, 155, College Station TX, pp 7-33

Posamentier HW, Erskine RD, Mitchum RMJ (1991) Models for submarine-fan deposition within a sequence-stratigraphic framework. In: Weimer P, Link MH (eds) Seismic Facies and Sedimentary Processes of Submarine Fans and Turbidite Systems. Springer-Verlag, New York, pp 127-136

Reading HG, Richard MT (1994) The classification of deep-water siliciclastic depositional systems by grain size and feeder systems, AAPG Bull 78:792-822

Shanmugam G (2000) 50 years of the turbidite paradigm (1950s-1990s): deep-water processes and facies models- a critical perspective, Mar and Petrol Geol 17:285-342

Shanmugam G, Moiola RJ (1982) Eustatic control of turbidites and winnowed turbidite. Geology 10:231-235.

Shanmugam G, Moiola RJ (1988) Submarine Fans: Characteristics, Models, Classification, and Reservoir Potential, Earth-Sci Rev 24:383-428

Stanley DJ, Rehault J-P, Stuckenrath R (1980) Turbid-layer by-passing model: the Corsican Trough, northwestern Mediterranean. Mar Geol 37:19-40

Stow DAV, Mayall M (2000) Deep-water sedimentary systems: New models for the 21st century. Mar and Petrol Geol 17:125-135 
Zaragosi S (2001) Les systèmes turbiditiques profonds de la marge celtique-armoricaine (Golfe de Gascogne): physiographie et évolution au cours des derniers 30000 ans. Ph.D. thesis, Univ. Bordeaux 1, n02264, 291p

\section{Figure Captions}

Figure 1: Morpho-sedimentary map of the Golo depositional system showing the main morphological features, recent and modern sedimentation, and location of studied cores. Contours of the bathymetric map are in metres. White areas correspond to areas with no data.

Figure 2: Photography and X-ray image of the sand facies recognized on the Golo turbidite system. A: massive or with various dynamic structures graded sand; B: fine sand with climbing ripples; C: laminated graded sand; D: massive sand; E: coarse homogeneous shells sand. F: Map of the core facies distribution on the Golo margin. Comparison with $3.5 \mathrm{kHz}$ echofacies of Gervais (2002).

Figure 3: Schematic types of sedimentary sequences observed in cores on the Golo margin.

Fig. 4: Sequence I and Itr: photograph, processed X-ray image and grain size curve showing vertical succession of structure and normally graded sand. Interval from core Kco 58 in the South Golo channel (see Fig. 1 for core location).

Figure 5: Photograph and grain size curve showing structureless non-graded sandy sequence II. Examples are from core Kcor 01 on the St Damiano Levee (see Fig. 1 for core location).

Figure 6: Map of superficial sediment distribution on the Golo margin indicating percentage of clay, silt and sand.

Figure 8: Core logs of the four cores collected onto the Pianosa Ridge showing the main lithologic facies variations (see Fig. 1 for core location).

Figure 9: Seismic profiles illustrating litho-seismic correlations on the South Golo lobe.

Figure 10: Core logs of the six cores collected on the South Golo channel-levee complex showing the main lithologic facies variations. Lateral correlation using carbonate content measurements is also shown (see Fig. 1 for core location).

Figure 11: Core logs of the two cores collected on the St Damiano channel-levee complex showing the main facies variations. Lateral correlation using carbonate content measurements is also shown (see Fig. 1 for core location). 
Figure 12: Core logs of the five cores collected on the Fium Alto Gully and lobe showing the main facies variations. Lateral correlation using carbonate content measurements is also shown (see Fig. 1 for core location).

Figure 13: Seismic profiles illustrating litho-seismic correlations on the Pineto lobe.

Figure 14: Core logs of the five cores collected on the South Golo lobe showing the main facies variations. Lateral correlation using carbonate content measurements is also shown (see Fig. 1 for core location).

Figure 15: Detailed bathymetric map of the South Golo lobe showing A: the location of seismic profile and MD 012434 core. B: Core log, ${ }^{14} \mathrm{C}$ dating, $\delta^{18} \mathrm{O}$ isotopic curve, position of regional seismic markers J, K, L and sea-level curve extrapolated from model of Lamberk and Bard (2000). C: Seismic profile through the South Golo lobe showing the correlation between the MD 012434 core and the seismic markers K, L and M from Gervais (2002) and Gervais et al. (2004 and 2006).

Figure 16: Type of flows along the Golo margin. The arrow length is proportional to the relative importance of the process.

Figure 17: Conceptual model showing the evolution of the Golo margin during late Quaternary. A. Slow and small amplitude relative sea-level fall: moderate turbidite activity. B. Rapid and high-amplitude relative sea-level fall or relative sea-level lowstand. High turbidite activity. C. Relative sea-level rise: small turbidite activity. D. Present situation. Relative sea-level highstand: hemipelagic deposition. 


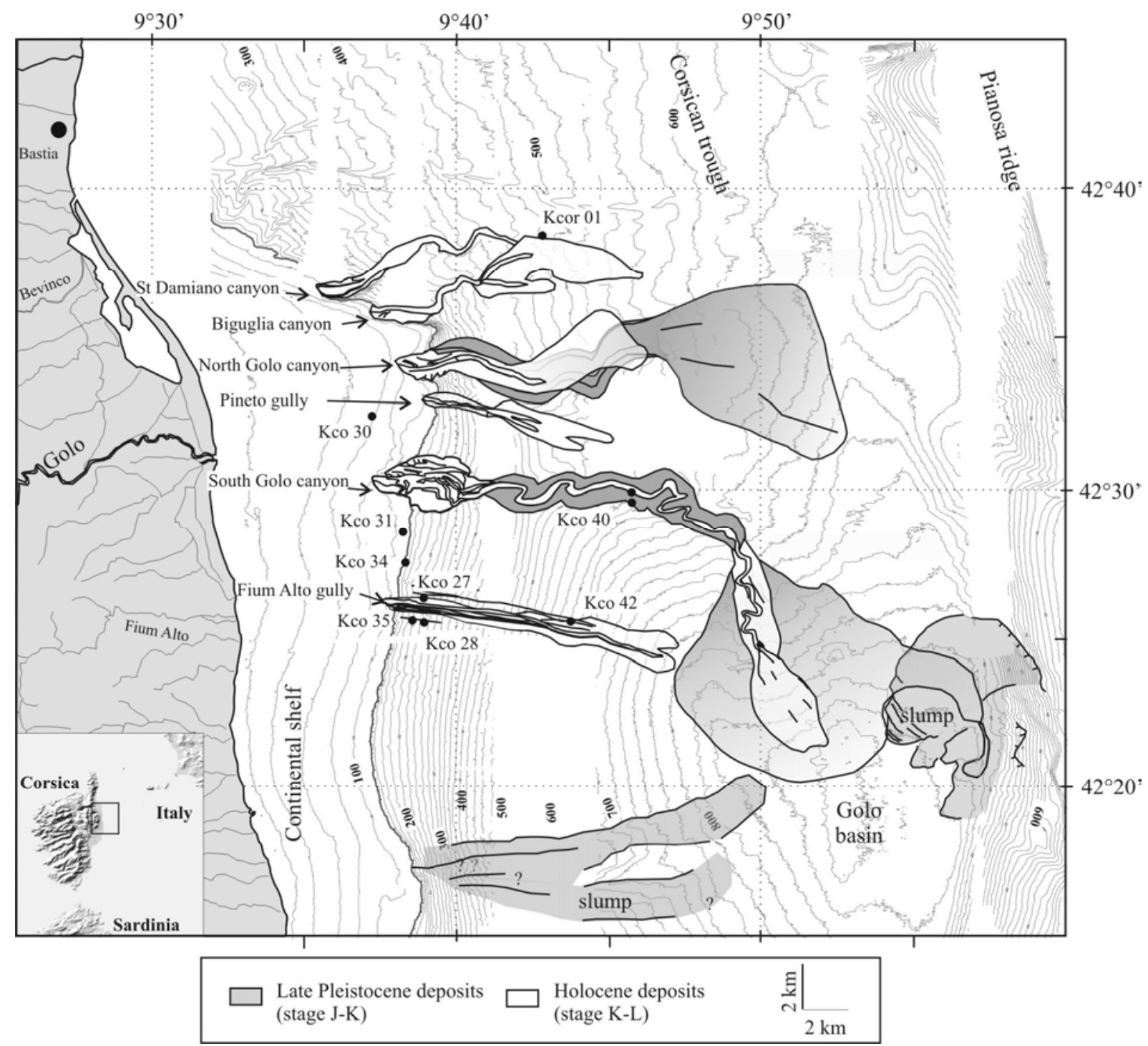

Fig. 1 


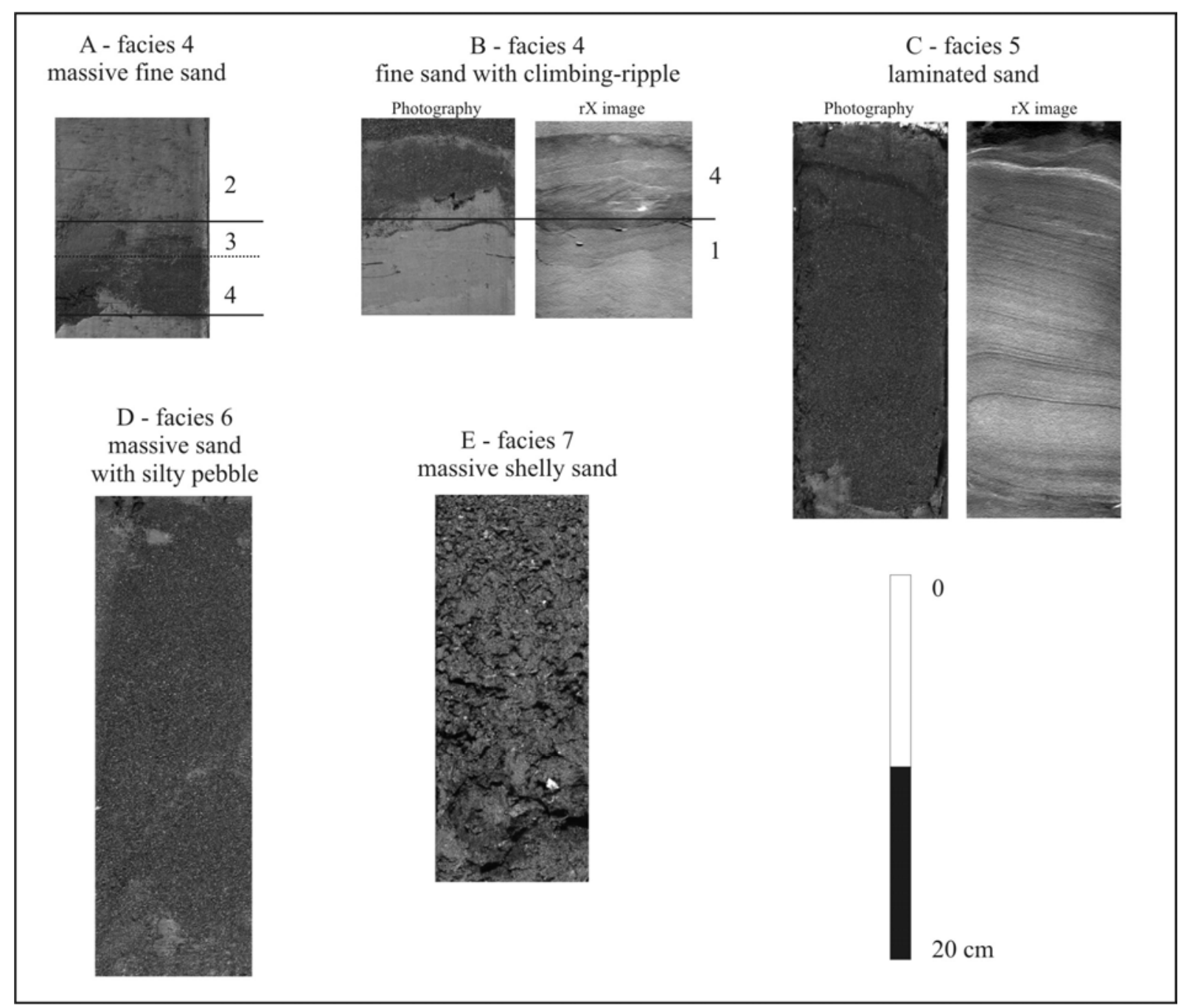

Fig. 2 
Sequence I

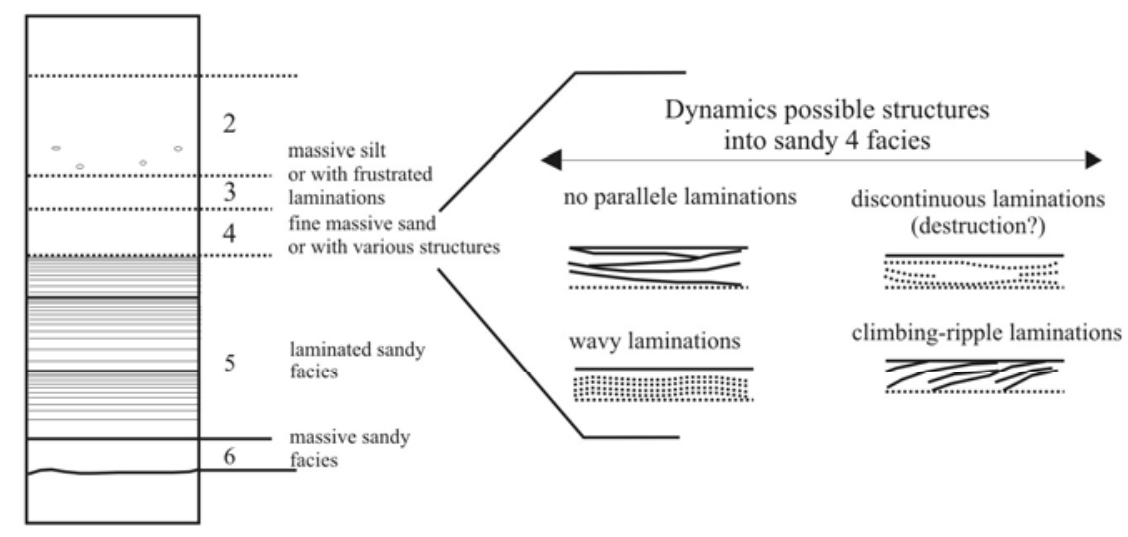

Sequence II

Sequence III
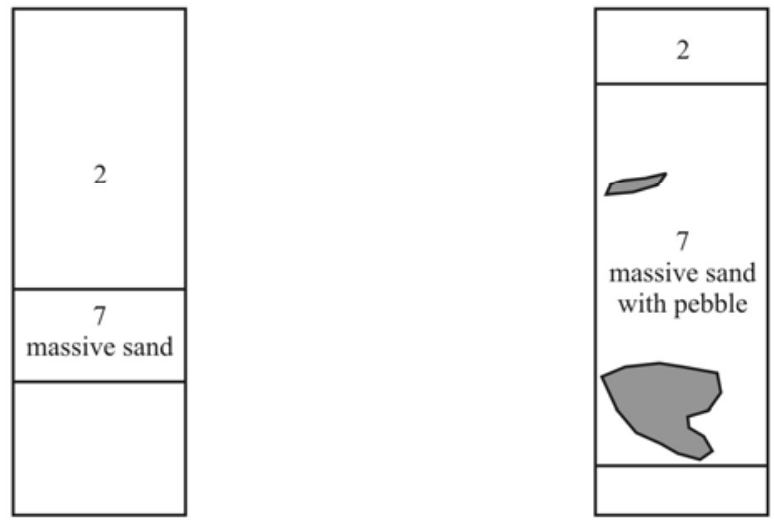

Fig. 3 


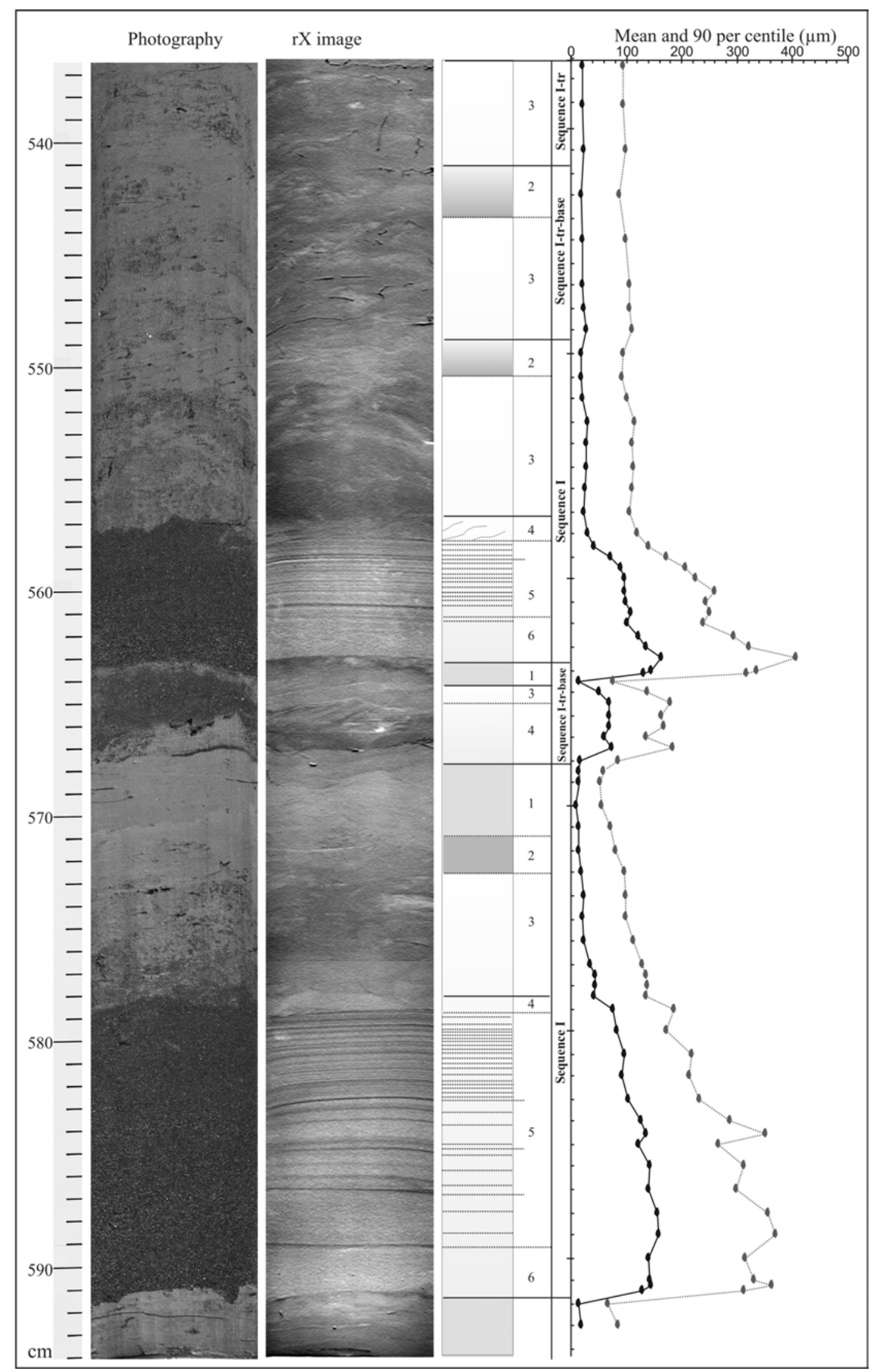

Fig. 4 


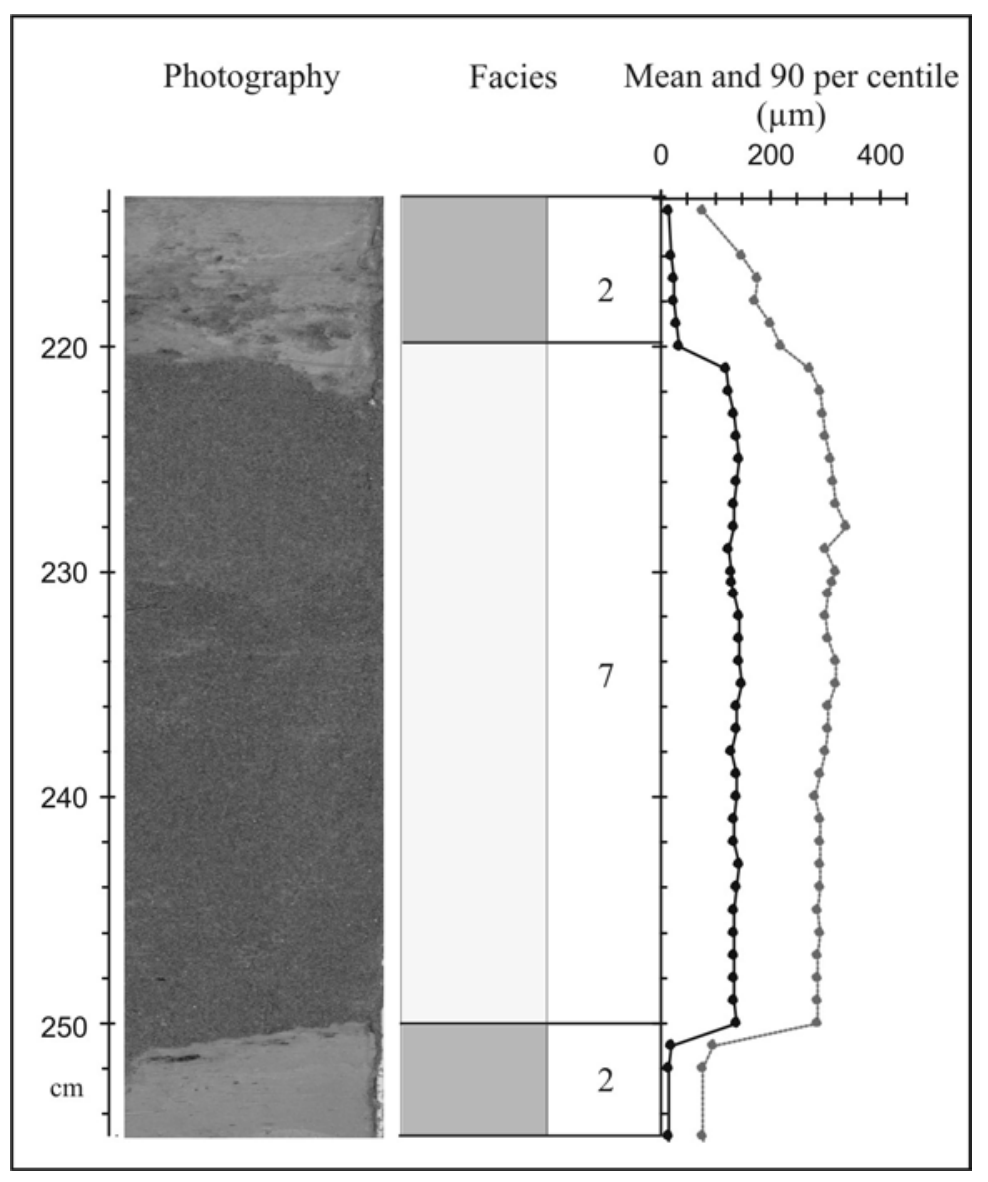

Fig. 5 


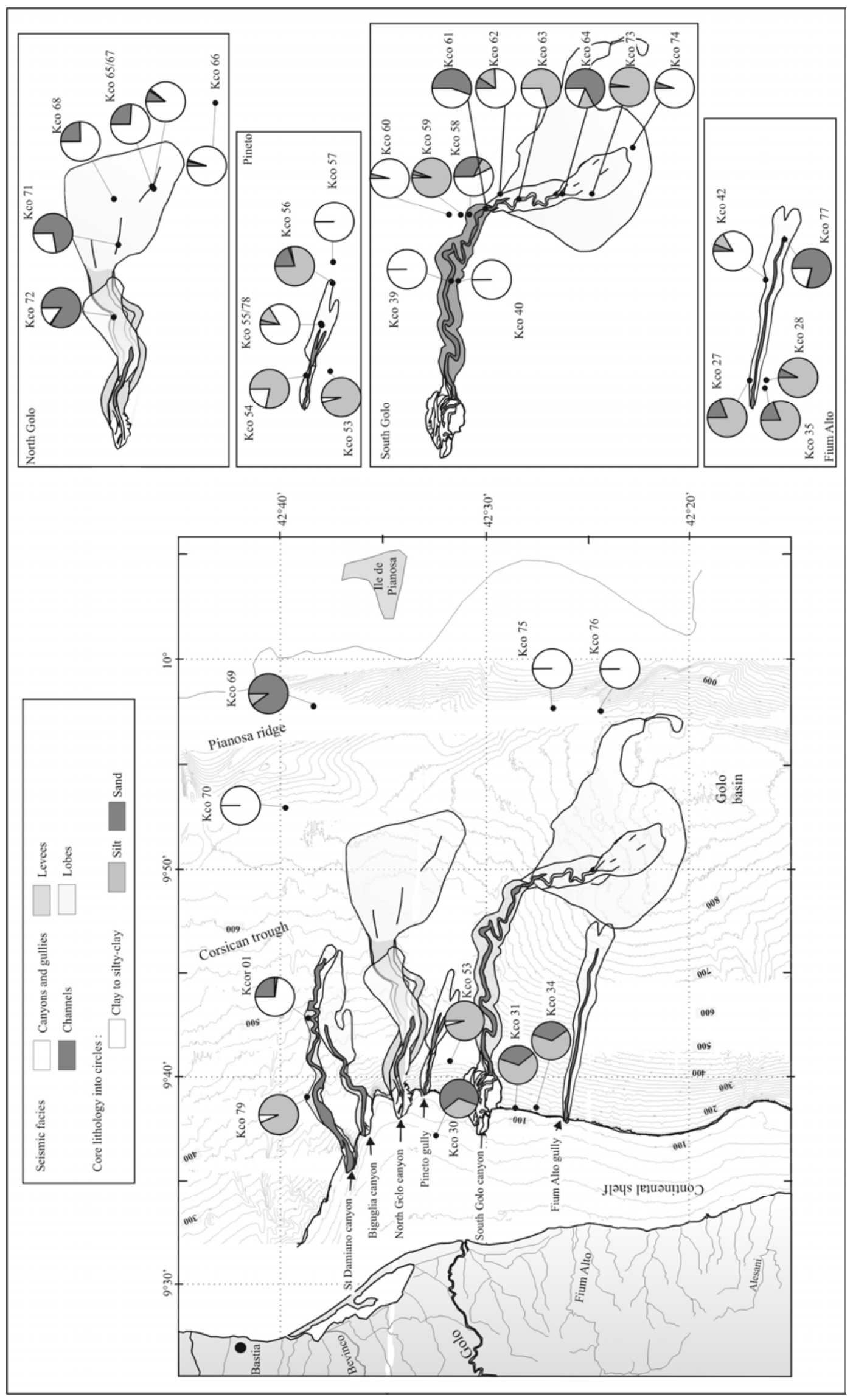

Fig. 6 


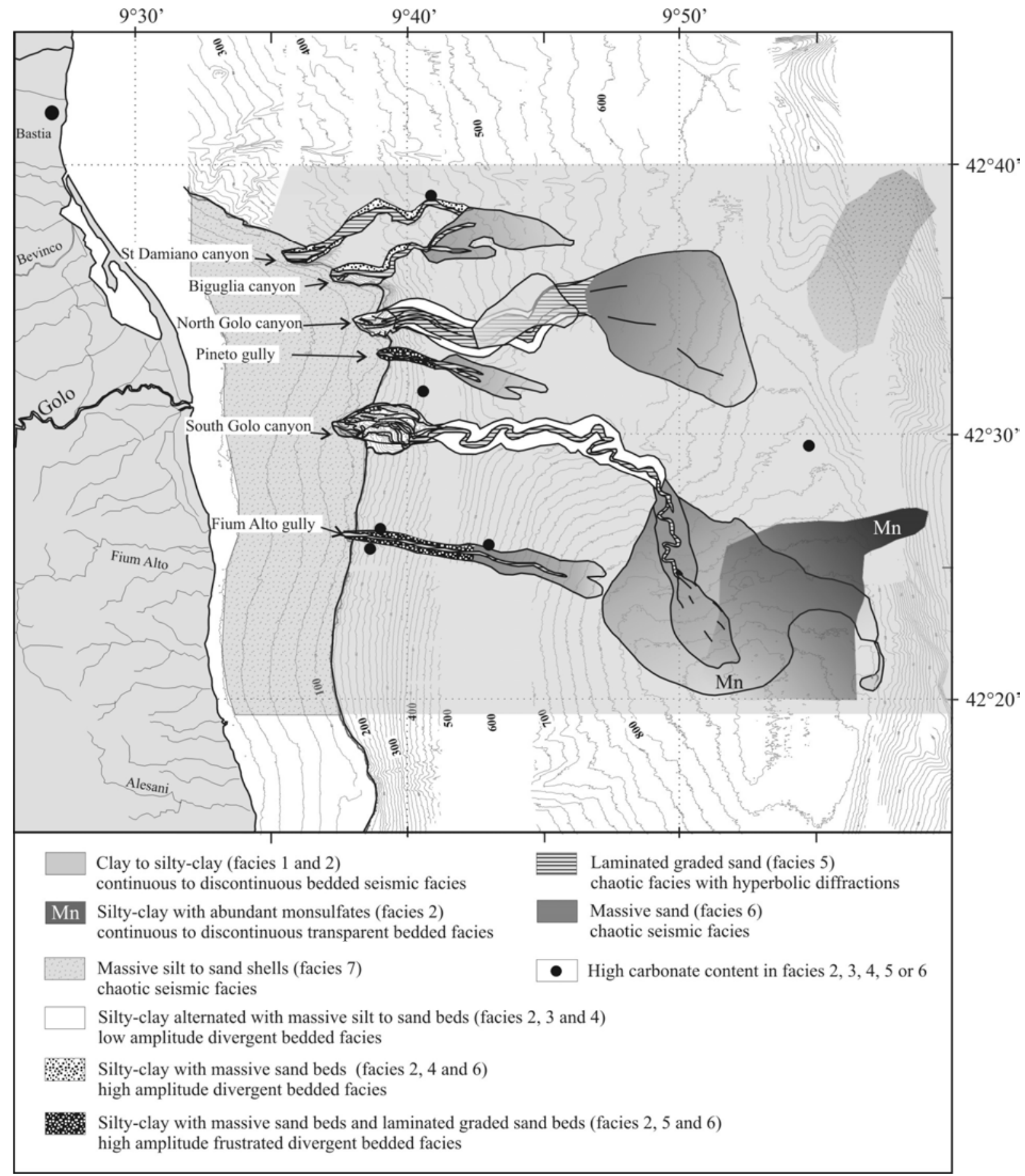

Fig. 7 


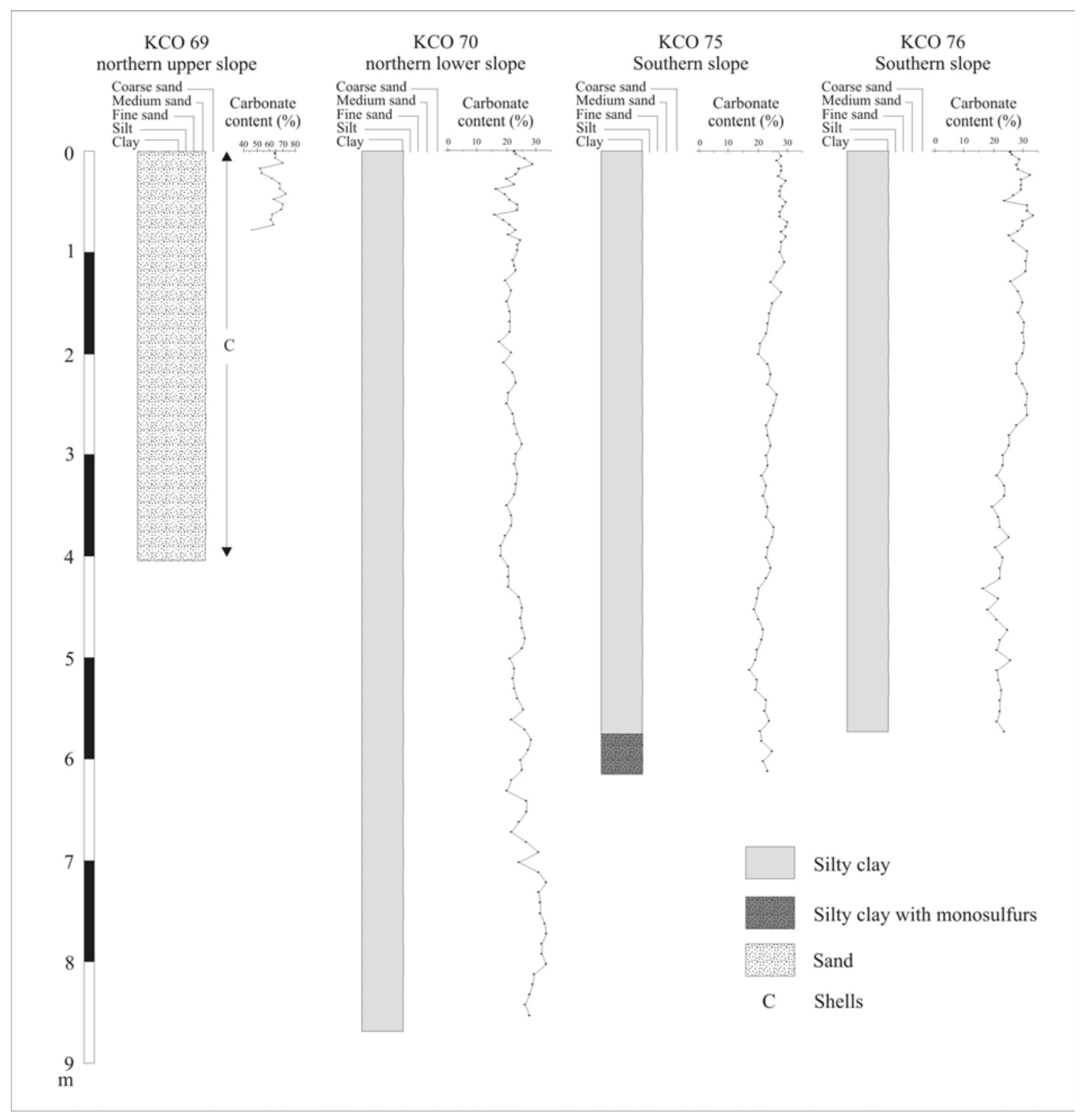

Fig. 8 

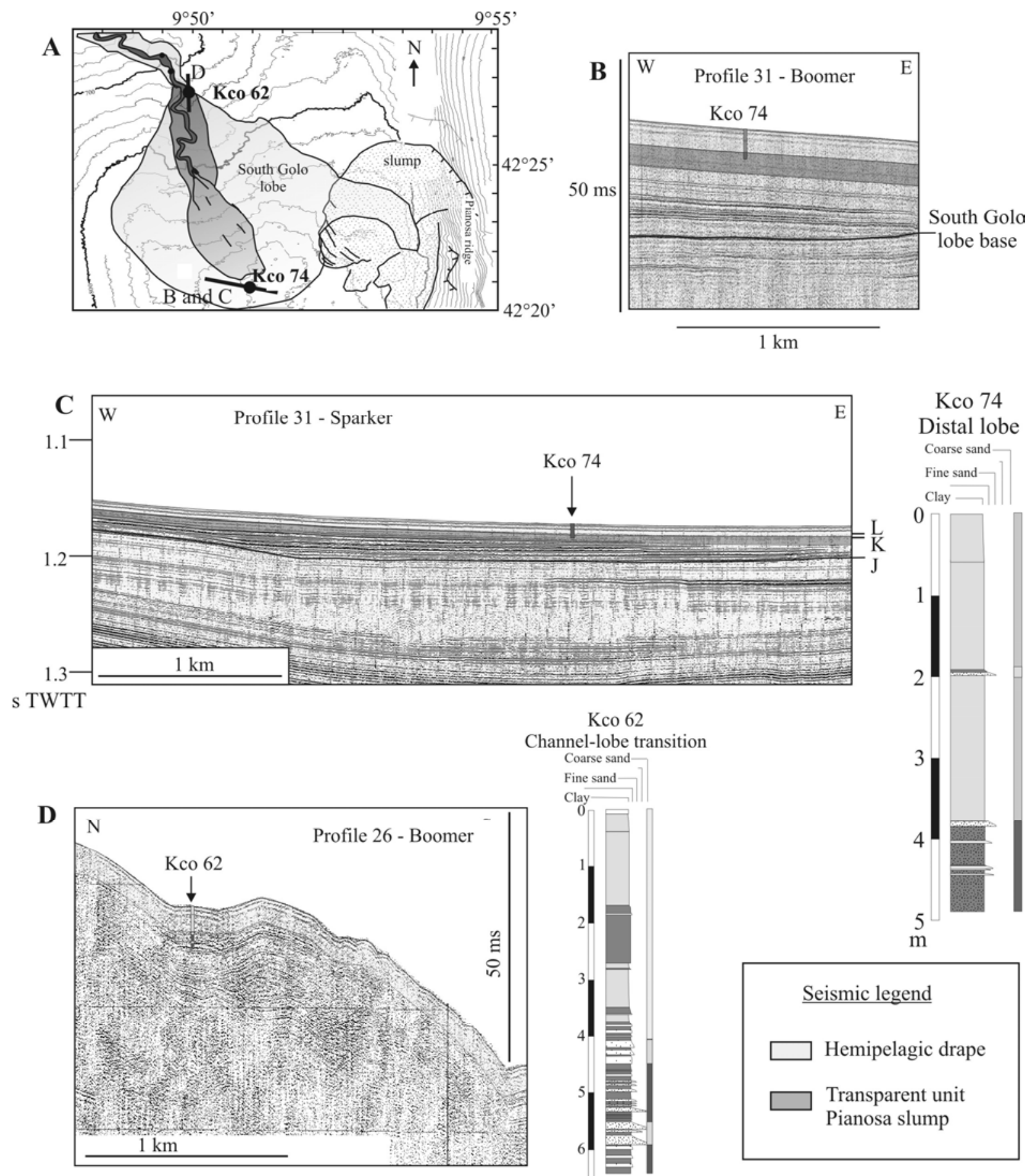

Kco 74

Distal lobe

Coarse sa

Fine sand -

0
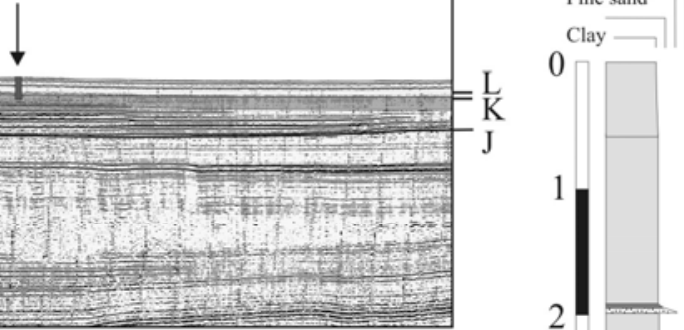

Kco 62

Channel-lobe transition

Coarse sand-

Fine sand

Clay-
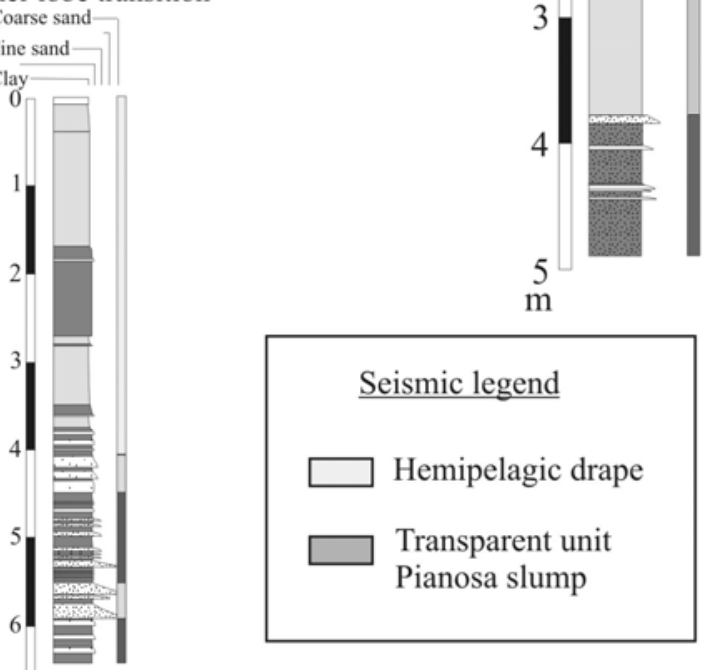

$\underline{\text { Seismic legend }}$

Hemipelagic drape

Transparent unit Pianosa slump

Fig. 9 


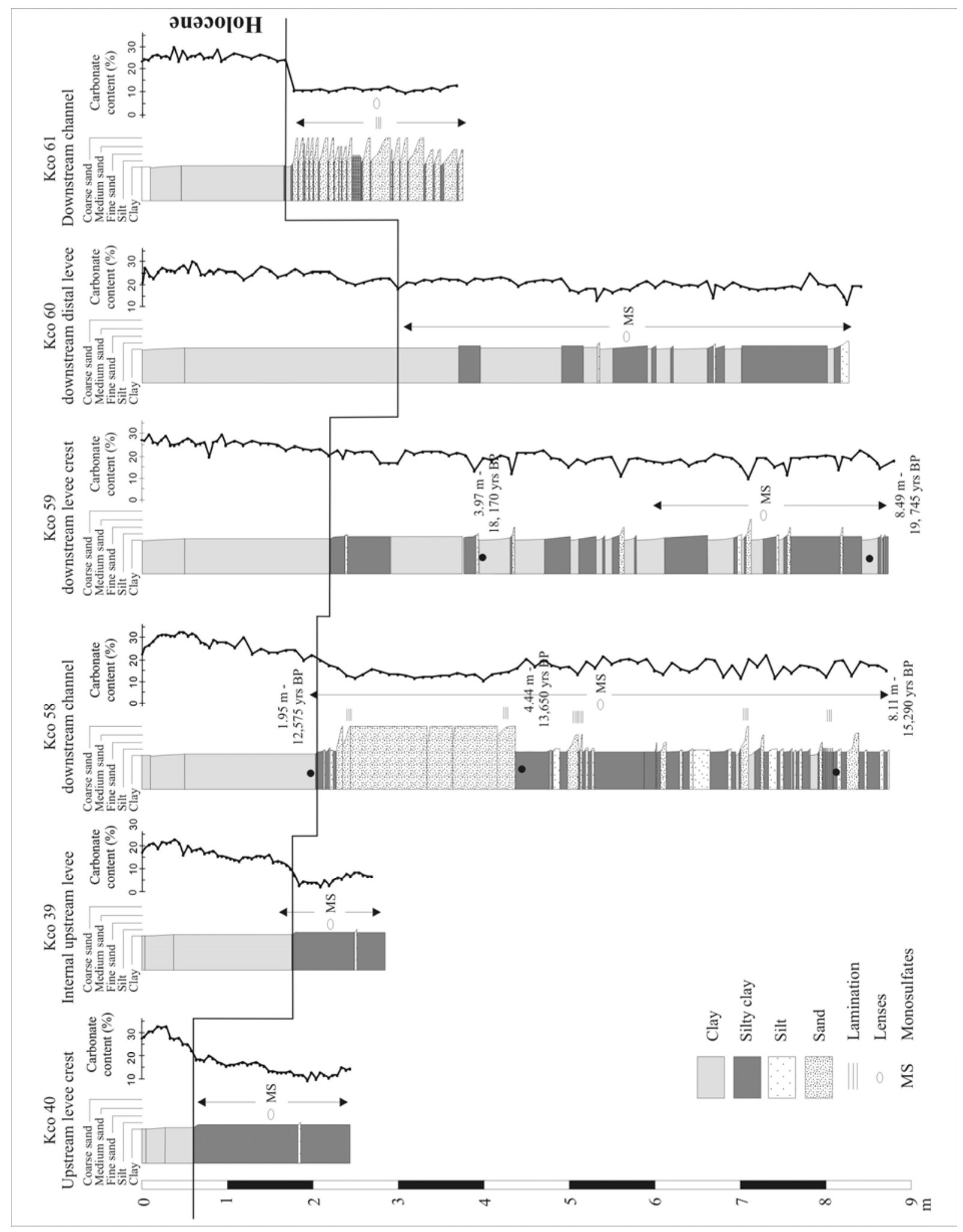

Fig. 10 


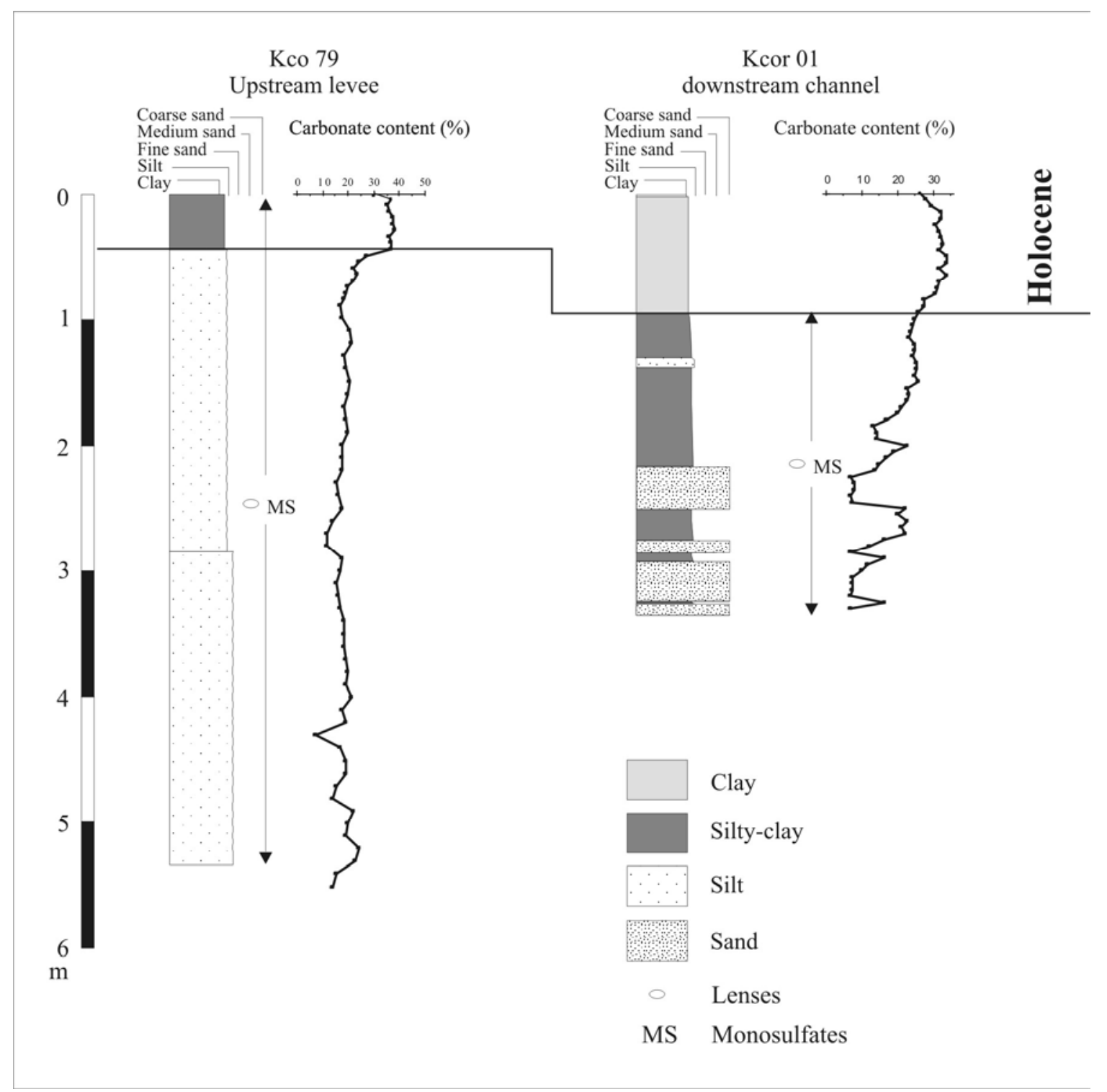

Fig. 11 


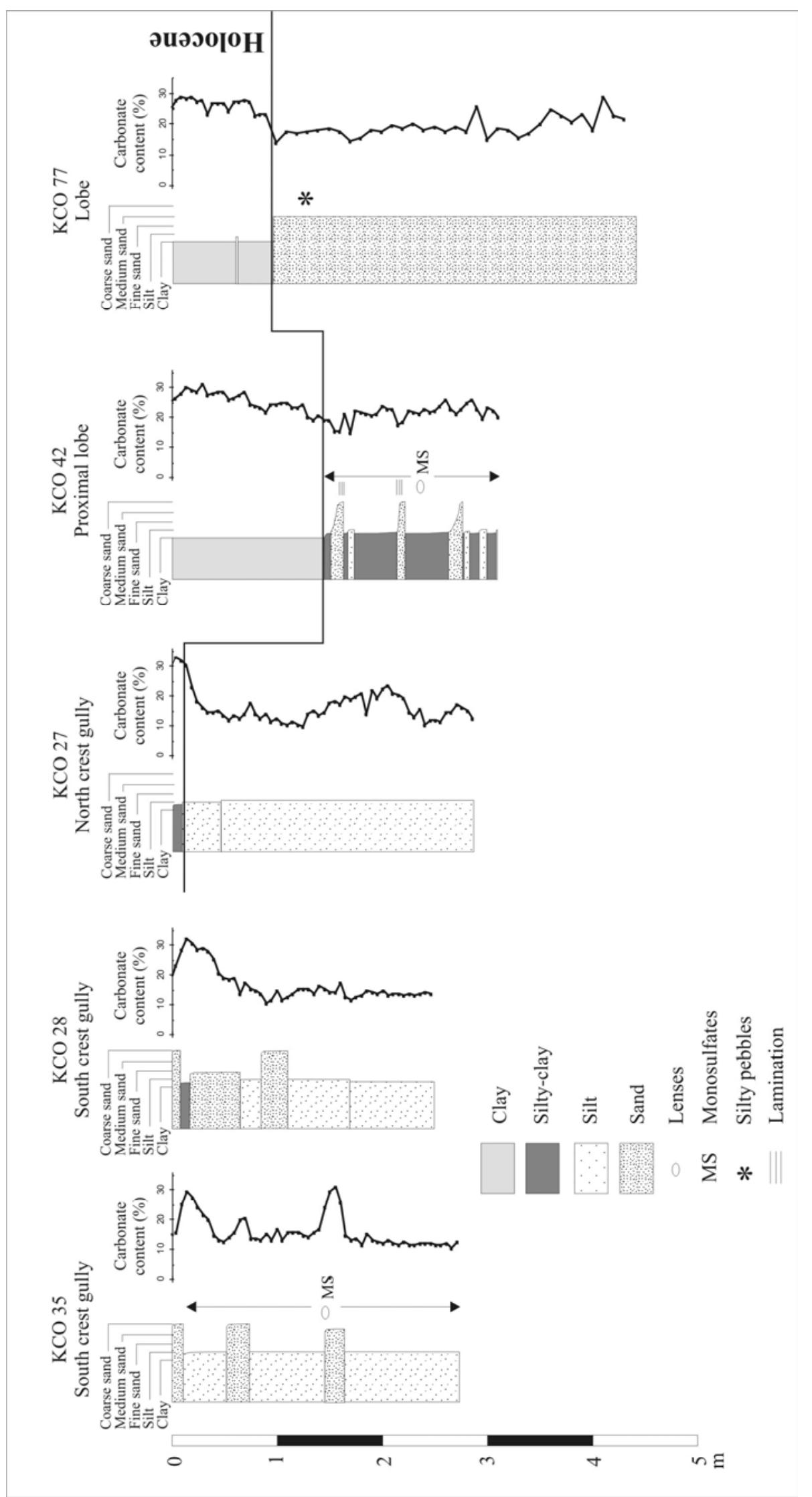

Fig. 12 


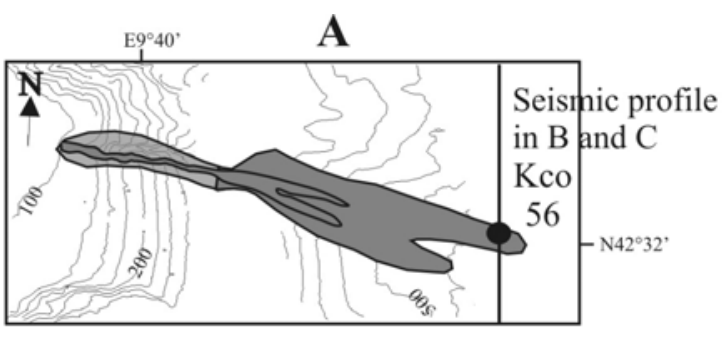

Seisnnic profile

$\mathrm{B}$ and $\mathrm{C}$

seismic

Kco 56

distal lobe

scale

$11 \mathrm{~km}$

B Sparker seismic profile

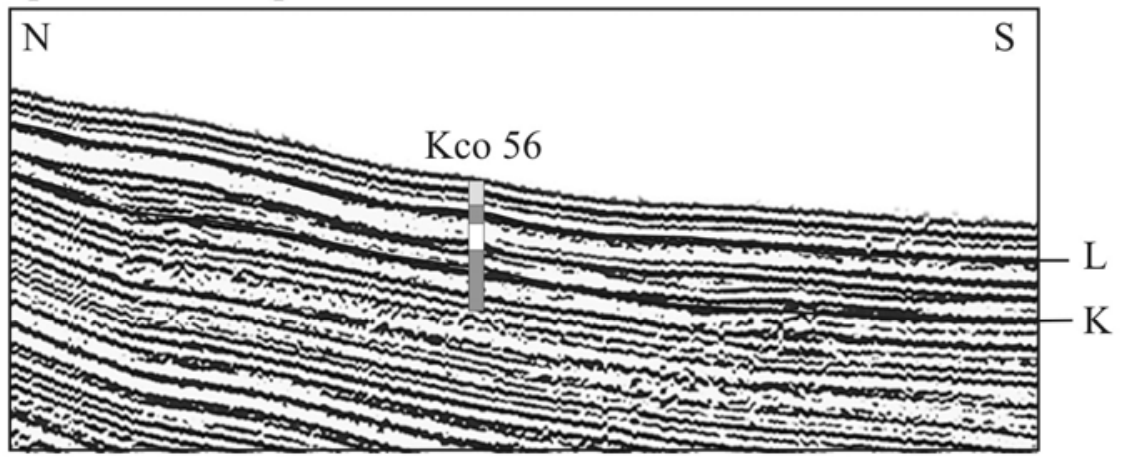

C Boomer seismic profile
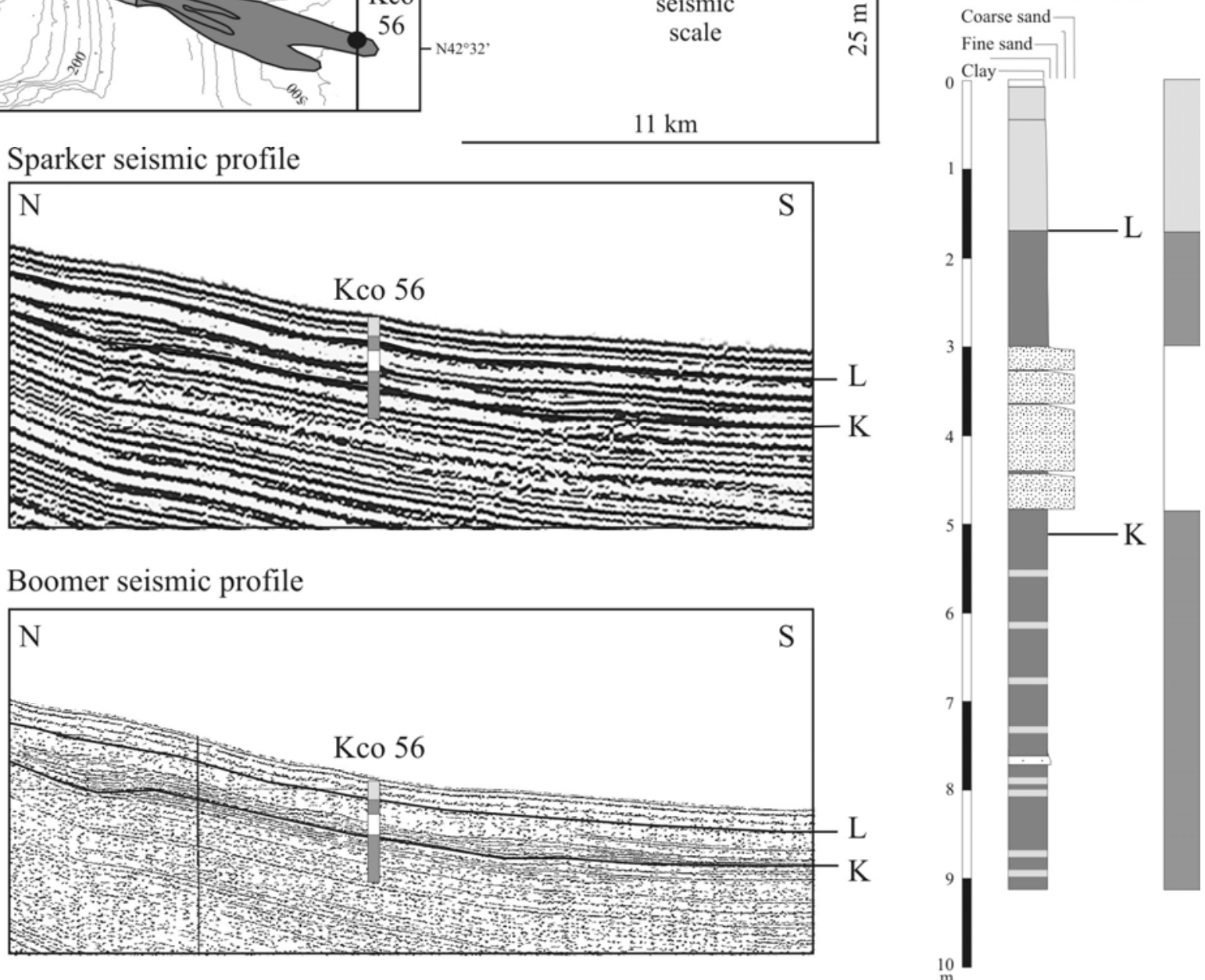

Fig. 13 


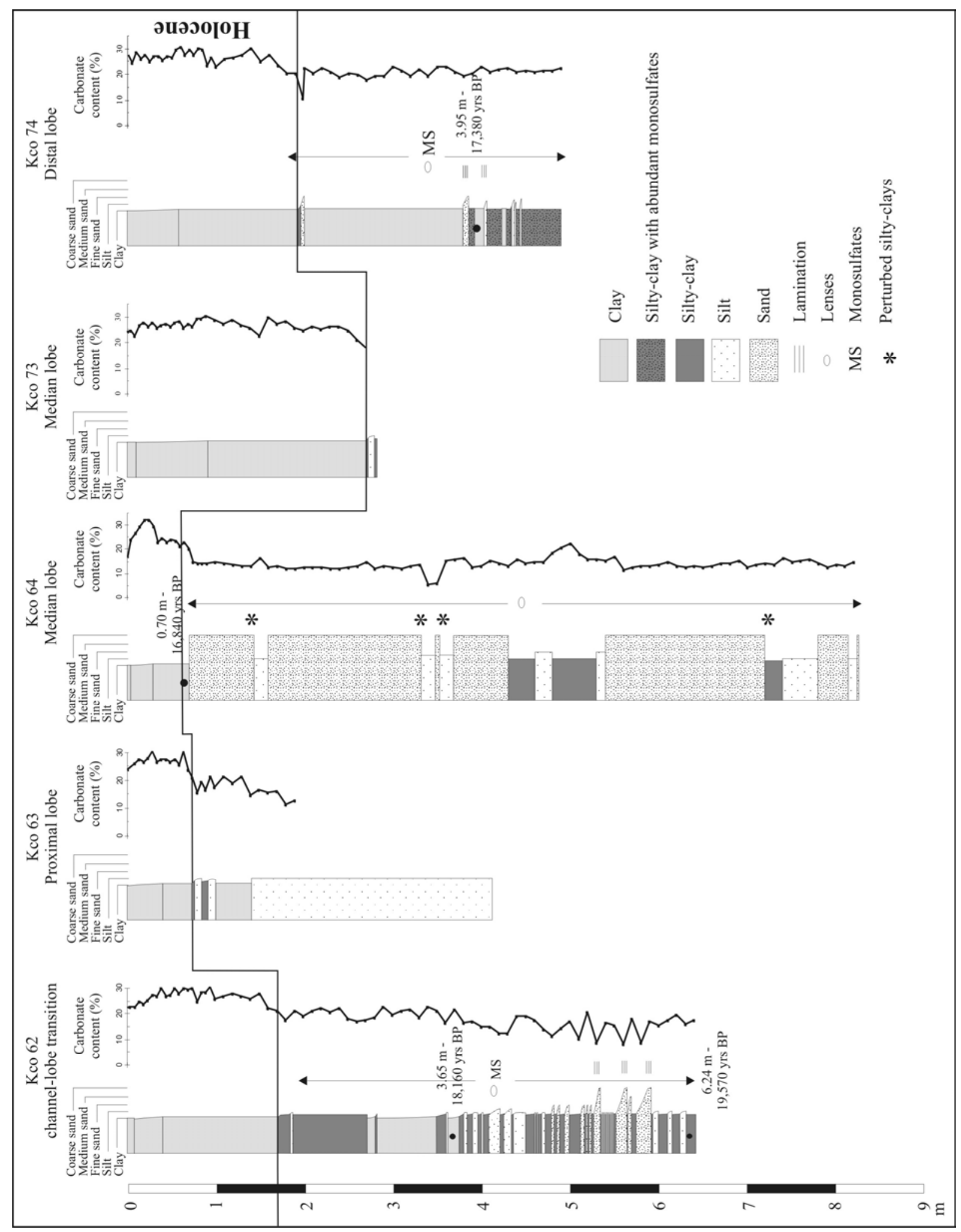

Fig. 14 


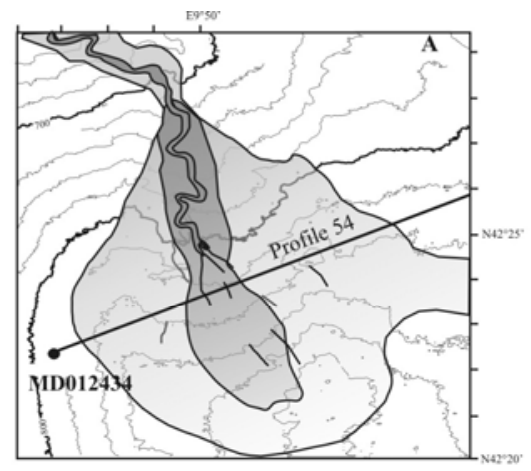

Holocene lobe (stage K-L)

Late Pleistocene lobe (stage J-K)

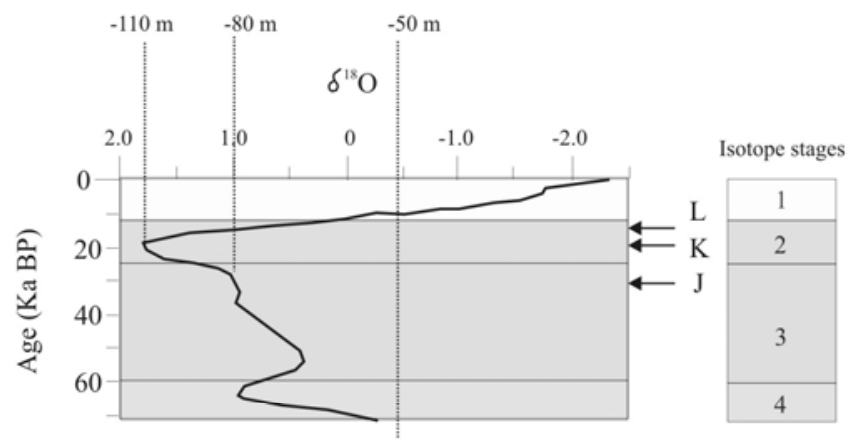

B MD 01-2434
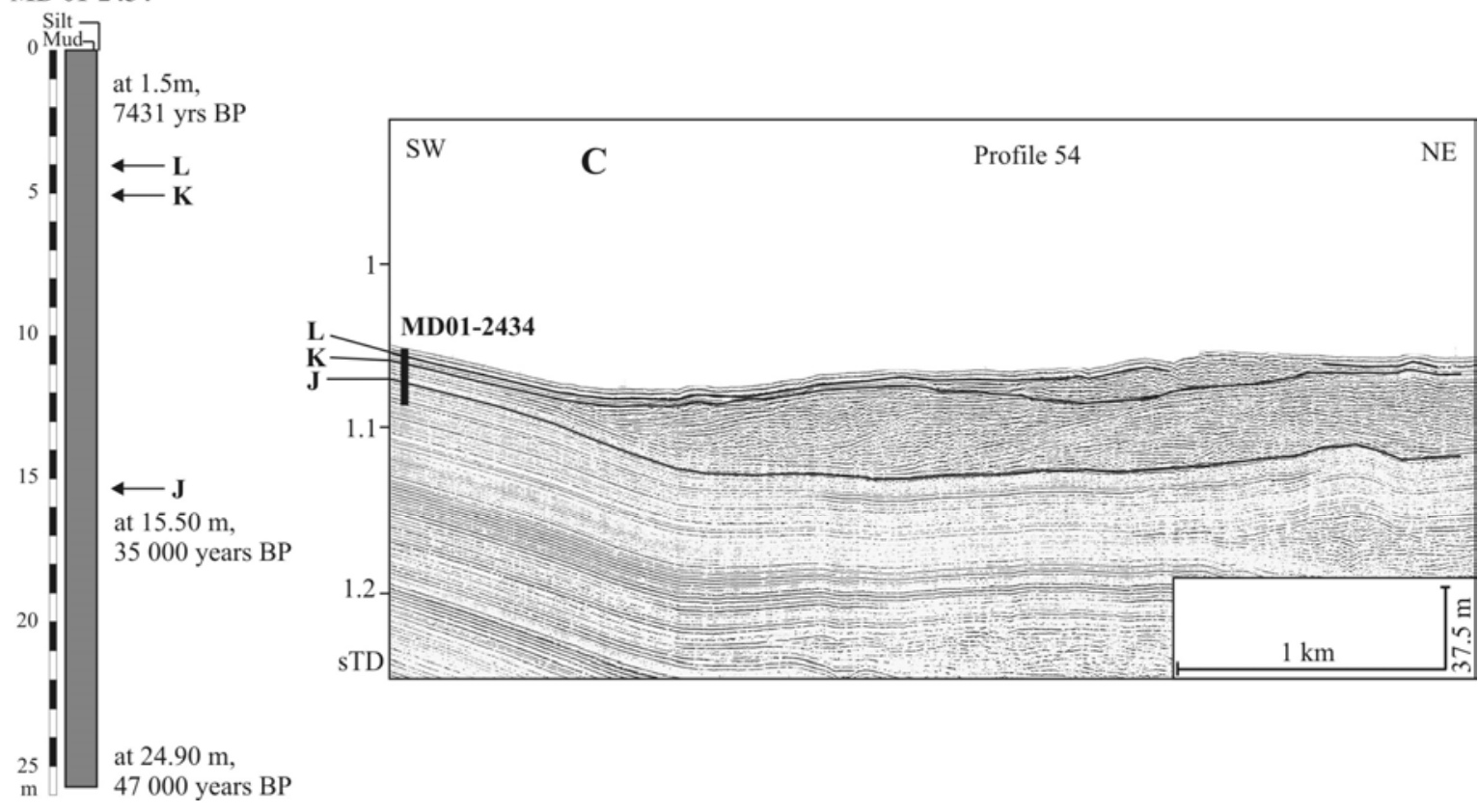

Fig. 15 


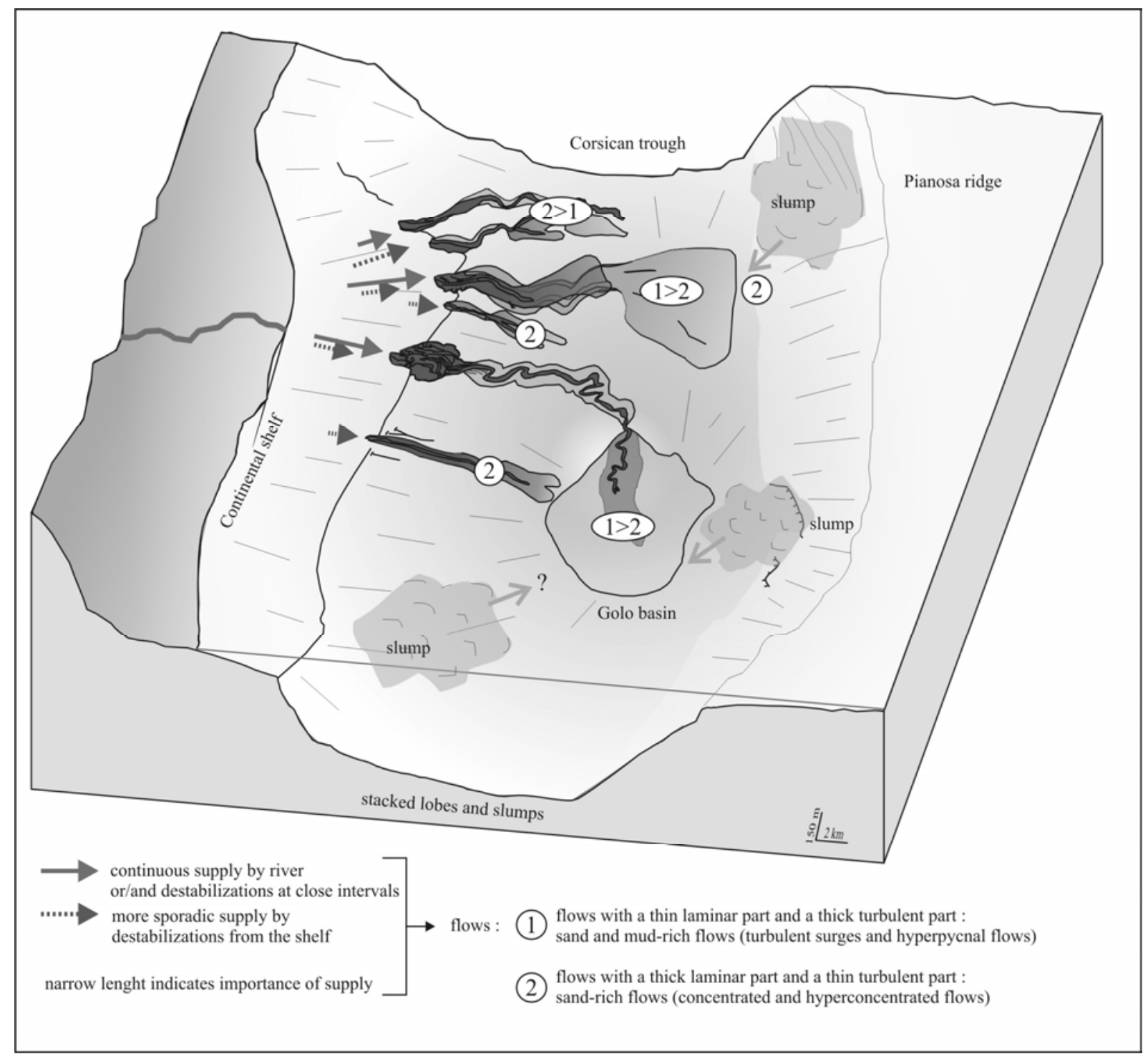

Fig. 16 

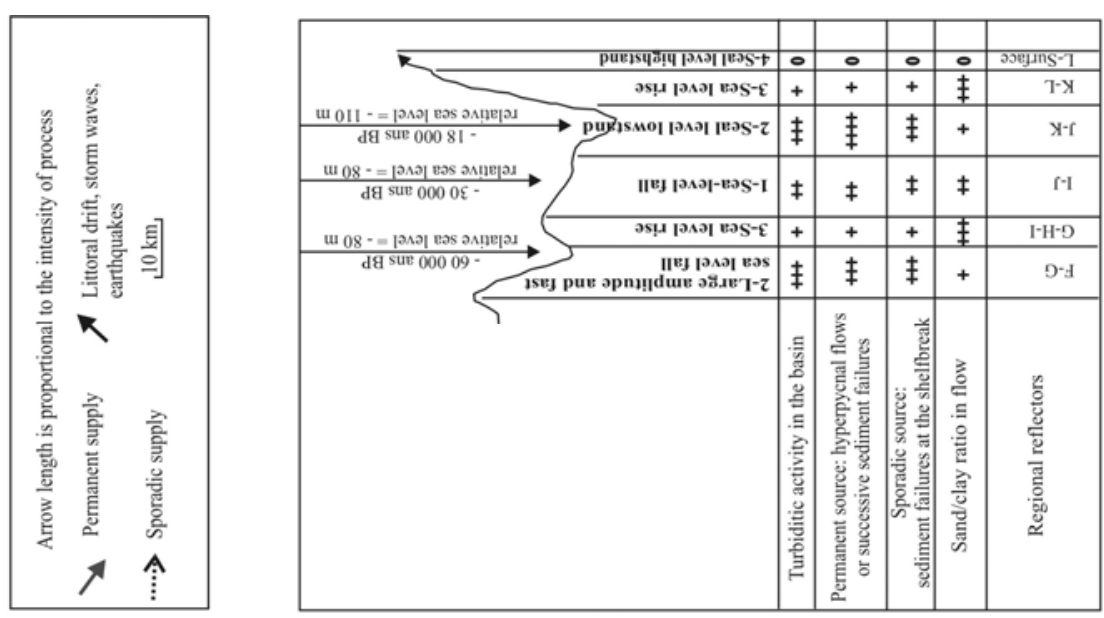

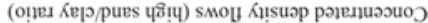
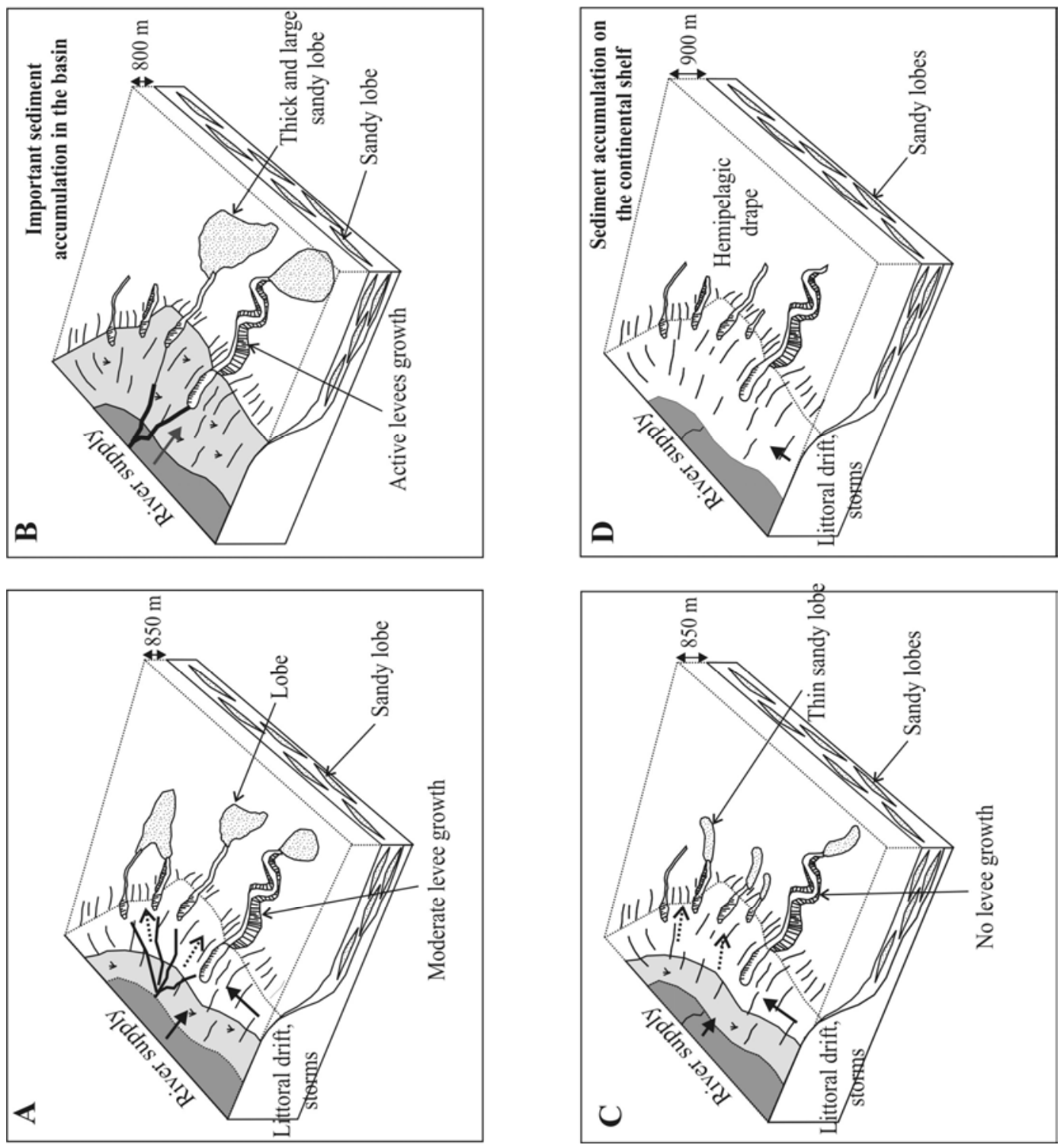

Fig. 17 